\title{
The Cult of Roman Shukhevych in Ukraine: Myth Making with Complications
}

\author{
Per Anders Rudling \\ Associate Professor of History at Lund University, Department of History, \\ Sweden; Senior Visiting Fellow at the National University of Singapore, \\ Department of History \\ per_anders.rudling@hist.lu.se; hisrpa@nus.edu.sg
}

\begin{abstract}
Ukrainian president Viktor Iushchenko's posthumous designation of Roman Shukhevych (1907-1950), the supreme commander of the Ukrainian Insurgent Army (UPA) as a Hero of Ukraine in 2007 triggered intense, and polarized debates in Ukraine and abroad, about Second World War-era Ukrainian nationalism and its place in history. Particularly sensitive are Roman Shukhevych's whereabouts in 1940-1943, when he served in German uniform, as a Hauptmann, or captain, in the battalion Nachtigall in 1941 thereafter, in 1942-1943 in Schutzmannschaft battalion 201, taking part in 'antipartisan operations' in occupied Belarus. This article analyzes the controversy regarding the memory of Roman Shukhevych.
\end{abstract}

\section{Keywords}

Roman Shukhevych (1907-1950) - Organization of Ukrainian Nationalists (OUN) Ukrainian Insurgent Army (UPA) - Ukraine - far right - collaboration - Second World War

1 An earlier version of this article was presented as 'The Shukhevych Cult in Ukraine: Myth Making with Complications' at the conference 'World War II and the (Re)Creation of Historical Memory in Contemporary Ukraine', Kyiv, Ukraine, September 23-26, 2009, accessed March 31, 2016, http://ww2-historicalmemory.org.ua/docs/eng/Rudling.doc. The author wishes to acknowledge the very helpful feedback provided by two anonymous reviewers.

(C) RUDLING, 2016 | DOI 10.1163/22116257-00501003

This is an open access article distributed under the terms of the Creative Commons Attribution 3.0

Unported (CC-BY-NC 3.0) License. http://creativecommons.org/licenses/by/3.0/Brill. com-4/26/2023 11:27:10AM 
On October 12, 2007, in order to mark the 65th anniversary of the founding of the Ukrains'ka Povstans'ka Armiia [UPA; Ukrainian Insurgent Army] and the centennial of the birth of its commander, Roman Shukhevych (1907-1950), Ukrainian president Viktor Iushchenko (b. 1954) posthumously awarded Shukhevych the highest honor of the Ukrainian state - the order of Hero of Ukraine, 'in recognition of his special contributions to the national liberation struggle for the freedom and independence of Ukraine.'

Iushchenko's designation of Shukhevych as a national hero was intended as a state endorsement of the organizations he led; in addition to commanding the UPA Shukhevych was the de facto leader of the Bandera wing of the Orhanizatsiia Ukrains'kykh Natsionalistiv [oun(b); Organization of Ukrainian Nationalists], during most of 1943 and 1944. The president stated that his recognition of the insurgents was necessitated by the importance of establishing the historical truth about the activities of the UPA, ${ }^{3}$ identifying its two enemies as Nazism and Communist terror.

Roman Shukhevych remains a highly controversial and divisive person in Ukrainian history. A freedom fighter and martyr for Ukraine to some, a Nazi collaborator to others. Iushchenko's decision exposed the divided and polarized historical memory in post-Soviet Ukraine. Brought to power in a wave of popular protest against a corrupt government's falsification of elections, Iushchenko's own term in office, from 2005 to 2010, was marred by inefficiency, infighting, and an inability to address the pressing concerns about misrule, endemic corruption, and abuse of power that had fueled the wave of popular protest that brought him to power. Under Iushchenko, Ukraine remained one of the most poorly governed states in Europe. ${ }^{4}$ Pressing concerns such as

2 Viktor Iushchenko, 'Ukaz prezydenta Ukrainy No. 965/2007 pro prysvoennia R. Shukhevvychu zvannia Heroi Ukrainy,' President of Ukraine: Official Website, October 12, 2007, accessed February 22, 2008, http://www.president.gov.ua/documents/6808.html. In August, 2011, under Ianukovych's administration, the title was revoked, not by the president, but by the Supreme Administrative Court of Ukraine, due to a technicality. As the title 'Hero of Ukraine' can only be bestowed to citizens of Ukraine, the conferring of these titles, posthumously, on Shukhevych and Bandera were ruled invalid. 'Higher Administrative Court rules Shukhevych's Hero of Ukraine title illegal,' Kyiv Post, August 2, 2011, accessed April 6, 2016, http://www.kyivpost.com/article/content/ukraine/higher-administrative-court-rules -shukhevychs-hero-109922.html.

3 'Iushchenko doruchav Tymoshenko vyznaty UPA,'Ukrains'ka Pravda, October 14, 2007, accessed November 18, 2007, http://www.pravda.com.ua/news/2007/10/14/65361.htm.

4 Andrew Wilson, 'Ukrainian Politics since Independence,' in Ukraine and Russia: People, Politics, Propaganda and Perspectives, ed. Agnieszka Pikulicka-Wilczewski and Richard Sakwa (Bristol: E-International Relations Publishing, 2015), 103. 
corruption, social cohesion, and economic performance largely went unaddressed. Iushchenko, however, left a more discernable legacy in regards to politics of memory, some of it highly controversial, such as the decision to rehabilitate the legacy of Ukrainian radical nationalism of the 1930s and '4os.

Shukhevych was not the first radical nationalist to be reassessed by Iushchenko; in May, 2007 he issued a presidential edict to honor the memory of Iaroslav Stets'ko (1912-1986), who led the oun(b) 1968-1986, and his wife Iaroslava (1920-2003) who eventually succeeded her husband as leader of the oun(b) in $1991-2003 .{ }^{5}$ The couple were glorified in mass media; streets, squares, and buildings were renamed after them, a museum in their honor was to be established in Kyiv. ${ }^{6}$ After losing the first round of the 2010 presidential elections, Iushchenko in January, 2010 posthumously elevated oun(b) leader Stepan Bandera (1909-1959) to a national 'Hero of Ukraine,' triggering an intense debate on the legacy of the oun. ${ }^{7}$ The 'Bandera debate' took place at a dramatic junction in Ukrainian politics, as Iushchenko did not make it to the second round of the elections, and Ukrainians elected Viktor Ianukovych (b. 1950) and his Party of Regions to lead the country. ${ }^{8}$ As it is the name and person of

5 There is no academic biography on Iaroslav Stets'ko, self-proclaimed oun(b) 'Prime Minister' of Ukraine on June 30, 1941. A two-volume collection of his essays was posthumously published by the oun(b). Iaroslav Stets'ko, Ukrains'ka vyzvol'na kontseptsiia: Tvory, chastyna 1 (Munich: Orhanizatsiia ukrains'kykh natsionalistv, 1987); and Iaroslav Stets'ko, Ukrains'ka vyzvol'na kontseptiia: Tvory, chastyna 2 (Munich: Orhanizatsiia ukrains'kykh natsionalistiv, 1991). Scholarly works on Stets'ko's politics include Karel C. Berkhoff and Marco Carynnyk, 'The Organization of Ukrainian Nationalists and Its Attitude towards Germans and Jews: Iaroslav Stets'ko's 1941 Zhyttiepys,' Harvard Ukrainian Studies 23, no. 3/4 (1999) 149-184; Marco Carynnyk, 'A Knife in the Back of Our Revolution: A Reply to Alexander J. Motyl's "The Ukrainian Nationalist Movement and the Jews: Theoretical Reflections on Nationalism, Fascism, Rationality, Primordialism, and History", available at the website of the American Association for Polish-Jewish Studies, accessed April 5, 2016, http://www.aapjstudies.org/manager/ external/ckfinder/userfiles/files/Carynnyk\%2oReply\%2oto\%2oMotyl.pdf.

6 Viktor Iushchenko, 'Ukaz prezydenta Ukrainy No. 416/2007 Pro vshanuvannia pam'iati Iaroslava Stets'ka i Iaroslavy Stets'ko,' President of Ukraine: Official Website, accessed April 10, 2008, http://www.president.gov.ua/documents/6145.html.

7 On Stepan Bandera, see Grzergorz Rossoliński-Liebe, Stepan Bandera: The Life and Afterlife of a Ukrainian Nationalist: Fascism, Genocide, and Cult (Stuttgart: ibidem-Verlag, 2014). On the discussion, see Tarik Syryl [Cyril] Amar, Ihor Balyns'kyi, and Iaroslav Hrytsak, ed., Strasti za Banderuiu: statti ta esei (Kyiv: Hrani-T, 2010); Rossoliński-Liebe, Stepan Bandera, 459-530; Eleonora Narvselius, "The "Bandera Debate": The Contentious Legacy of World War II and Liberalization of Collective Memory in Western Ukraine,' Canadian Slavonic Papers 54, no. 3-4 (2012): 61-83.

8 As one analyst has noted, the ideology of Ianukovych's now-defunct Party of Regions defied Western political science definitions: 'unique in the former Soviet space in being launched 
Bandera, rather than Shukhevych that has come to be most intimately linked with Ukrainan radical nationalism, the 'Bandera debate' eventually came to eclipse the controversy surrounding the elevation of Shukhevych to national hero. At the time, however, this was a major symbolic event which polarized public opinion and sharply divided supporters and opponents of the decision, and, unlike previous controversial choices became a matter of international attention and protests.

The award ceremony for Shukhevych was preceded by a march of UPA veterans through Kyiv. Shukhevych's son Iuryi, the leader of the far-right paramilitary organization UNA-UNSO, accepted the medal on his father's behalf. ${ }^{9}$ Uniformed members of this, and other radical right-wing groups, dressed in brown shirts and black ties joined the UPA veterans. Far from becoming a dignified, solemn manifestation of a nation united behind the late UPA commander, the march degenerated into street brawls between octogenarian veterans of the Red Army and UPA, as well as between radical nationalists and protesters from the communist and progressive socialist parties. ${ }^{10}$ The small Ukrainian Jewish community was outraged.11

by a nexus of new oligarchs, old Soviet Red Directors, Pan-Slavic and regional activists, and organized crime figures,' it brought together 'oligarchs ... former Communist Party voters, and uph[e]ld Soviet ideological tenets, such as state paternalism, anti-fascist discourse, and distrust of the West, particularly the us and Nato.' Taras Kuzio, 'The Origins of Peace, Non-Violence, and Conflict in Ukraine,' in Ukraine and Russia: People, Politics, Propaganda and Perspectives, ed. Agnieszka Pikulicka-Wilczewski and Richard Sakwa (Bristol: E-International Relations Publishing, 2015), 111.

On unA-Unso, see Andreas Umland and Anton Shekhovtsov, 'Ultraright Party Politics in Post-Soviet Ukraine and the Puzzle of the Electoral Marginalism of Ukrainian Ultranationalists in 1994-2009,' Russian Politics and Law 51, no.5 (2013): 33-38; on Shukhevych's role in unA-Unso, see Per A. Rudling, 'Anti-Semitism and the Extreme Right in Contemporary Ukraine,' in Mapping the Extreme Right in Contemporary Europe: From Local to Transnational, ed. Andrea Mammone, Emmanuel Godin and Brian Jenkins (London and New York: Routledge, 2012), 189-205.

10 Pavel Korduban, 'Leftist, Pro-Russian Extremists defy Yushchenko over History, Eurasia Daily Monitor 4, no. 197 (October 24, 2007), accessed January 17, 2008, http://www .jamestown.org/edm/article.php/?article_id=2372530. Despite its name, Natalia Vitrenko's (b. 1951) Progressive Socialist Party could rather be placed on the far right, ideologically, being affiliated with the Lyndon LaRouche movement. On the Ukrainian Communist and Progressive Socialist parties, see Volodymyr Ishchenko, 'The Ukrainian Left During and After the Maidan Protests: Study requested by Die Linke delegation in the GUE/NGL,' (GUE/NGL, 2015), 13-17, accessed April 5, 2016, https://www.academia.edu/20445056/ The_Ukrainian_Left_during_and_after_the_Maidan_Protests.

11 Wadim Rabinowitsch, Jan Tabatschnik and Aleksandr Feldman, 'Jüdischer Protest in der Ukraine,' Kontakte-Kontakty: Verein für Kontakte zu Ländern der ehemaligen Sowjetunion, 
Speaking to a meeting of UPA veterans, Iushchenko stated that 'The memory of each hero and every victim of the struggle for Ukraine's liberation, freedom, and independence is sacred and undivisible .... Let us not avoid any difficult pages of our history and in such a way let us restore the truth which is based on the Ukrainian nation's great exploits - the exploits of the people who defeated death and established their state.'12

Against this backdrop, the credibility of Iushchenko's words about the establishment of historical 'truth' and an indivisible national memory was limited among many Ukrainians. Rather than promoting national reconciliation, the government's attempts to turn Shukhevych into a national hero opened up old wounds and exposed deep divisions in Ukrainian society - between the right and left, east and west, and between Ukrainian nationalists and representatives of the Jewish community. ${ }^{13}$

Given Iushchenko's expressed ambition of orienting Ukraine towards membership in the European Union and NATO, his designation of ultranationalist collaborators with Nazi Germany as national heroes paradoxically put some of his interpretations of history more at odds with the European mainstream than even Ianukovych and his pro-Russian electorate in the east. ${ }^{14}$

As Iushchenko and the western parts of Ukraine celebrated the centennial of Shukhevych's birth, the Kharkiv City Assembly, dominated by Ianukovych's Party of Regions, called on the public to stop glorifying the memories of oun and

October 15, 2007, accessed April 10, 2008, http://www.kontakte-kontakty.de/deutsch/ verein/2005-2009/upa.php.

12 'President speaks to UPA veterans,' Press Office of President Victor Yushchenko, October 14, 2007, accessed April 10, 2008, www.president.gov.ua/done_img/b/7/7836.jpg. On the discussions surrounding the event, see Olha Ostriitchouk, Les Ukrainiens face à leur passé: Vers une meilleure compréhension de clivage Est/Ouest (Brussels: Peter Lang, 2013), 343-345.

13 There is a consensus among sociologists and political scientists who study Ukraine's regions that regional differences do exist and are important. Whereas the east/west dynamic is real, these divisions are, however, complex, with sub-regions within regions. See, for instance, Yitzhak M. Brudny and Evgeny Finkel, 'Why Ukraine is not Russia: Hegemonic National Identity and Democratization in Russia and Ukraine,' East European Politics and Societies 25, no. 4 (2011): 813-833; Sebastian Klüsener, 'Die Regionen der Ukraine: Abgrenzung und Charakterisierung,' Ukraine-Analysen 23 (2007): 2-11; Ivan Katchanovski, Cleft Countries: Regional Political Divisions and Cultures in Post-Soviet Ukraine and Moldova (Stuttgart: ibidem-Verlag, 2006); Karina V. Korostelina, 'Mapping National Identity Narratives in Ukraine,' Nationalities Papers 41, no. 2 (2013): 293-315.

14 Andreas Umland, 'Die andere Anomalie der Ukraine: ein Parlament ohne rechtradikale Fraktionen, ' Ukraine-Analysen 41 (2008): 67-11, accessed May 1, 2009, http://www.laender -analysen.de/ukraine/pdf/UkraineAnalysen41.pdf. 
UPA. ${ }^{15}$ The Party of Regions described Shukhevych's award as an endorsement of integral nationalism and as an attack on the peoples of eastern Ukraine: 'the population of the non-western areas of Ukraine feel an ever stronger ideological pressure from the brand of Banderite Nazism and xenophobia. ${ }^{16}$ In the Verkhovna Rada, Ukrainian Communist Party leader Petro Symonenko (b. 1952), an ally of Ianukovych, protested 'the raising to sainthood today of one who received two Iron Crosses from the hands of Hitler with his order to celebrate his 10oth anniversary at an official level. ${ }^{17}$ Another high-profile communist, Oleksandr Holub, condemned the move as part of 'the president's attempts to impose pro-fascist, neo-Nazi policy on society.18 After UkrainianCanadian political scientist Petro Potichnyj (b. 1930), a former child soldier of the UPA and a leading authority on the history of his movement, refuted Symonenko's claims, ${ }^{19}$ the president of the Ukrainian World Congress responded by suing Symonenko for libel. ${ }^{20}$

\section{OUN and UPA}

Iushchenko's ambition of building national myths around the oun was controversial. Founded in 1929, the oun was the largest and most important Ukrainian far-right organization. Explicitly totalitarian, the movement embraced the Führerprinzip, a cult of political violence, racism, and an aggressive antiSemitism. ${ }^{21}$ It sought the establishment of Ukrainian statehood at any price,

15 Wilfried Jilge, 'Competing Victimhoods: Post-Soviet Ukrainian Narratives on World War II,' in Shared History - Divided Memory: Jews and Others in Soviet-Occupied Poland, 1939-1941, ed. Elazar Barkan, Elizabeth A. Cole and Kai Struve (Leipzig: Leipziger Universitätsverlag, 2008), 125, footnote 98.

16 Georgii Gerashchenko, 'Koe-chto o "zabyvchivosti” v panegirikakh Romanu Shukhevych,' Vremia Regionov Kharkovshchiny 27, no. 74 (2007), accessed May 18, 2008, http:// pr.kharkov.ua/full.php?g=newspaper\&id=1275.

17 Zenon Zawada, 'UWC president set to sue Communists over defamation of Roman Shukhevych,' The Ukrainian Weekly, August 26, 2007, accessed November 18, 2007, http:// www.ukrweekly.com/Archive/2007/340703.shtml.

18 Korduban, 'Leftist, Pro-Russian Extremists.'

19 Zawada, 'UwC president.' While Shukhevych did not himself earn an Iron Cross, Nachtigall soldier Iu. Lopatyns'kyi received the Iron Cross of the second class. Andrii Bolianovs'kyi, Ukrains'ki viis'kovi formuvannia v zbroinykh sylakh Nimechchyny (1939-1945) (L'viv: L'vivs'kyi Natsional'nyi Universytet im. Ivana Franka and Canadian Institute of Ukrainian Studies, 2003), 71. Petro J. Potichnyj, personal correspondence, May 24, 2008.

20 Zawada, 'UwC president.'

21 The most detailed recent studies on oun ideology of this period are Franziska Bruder, 'Den ukrainischen Staat erkämpfen oder sterben!': Die Organisation der Ukrainischen 
and utilized assassination as legitimate means to this end. A typical fascist movement, the ou cultivated close relations with Fascist Italy, Nazi Germany, the Spanish Falange, and the Croatian Ustaše. ${ }^{22}$ Following the 1938 assassination by the Soviet NKVD of its founding leader or vozhd', ${ }^{23}$ Evhen Konovalets' (1891-1938), the movement split in 1940, as his successor, his brother-in-law, Colonel Andrii Mel'nyk (1890-1964), was soon challenged by a faction of younger, more radical nationalists led by Stepan Bandera (1909-1959). The two wings, known as the ouN(m) and oun (b), both courted Nazi Germany, hoping to enlist support for Ukrainian statehood in the form of a Nazi client state of the Slovak or Croatian model. ${ }^{24}$ Certain circles in the Nazi leadership, particularly within the Abwehr - Germany's military intelligence agency - and Alfred

Nationalisten (oUN) 1929-1948 (Berlin: Metropol, 2007); Rossoliński-Liebe, Stepan Bandera; and Myroslav Shkandrij, Ukrainian Nationalism: Politics, Ideology, and Literature, 1929-1956 (New Haven, NJ: Yale University Press, 2015).

22 For a discussion on the oun's ideology, see Andreas Umland, 'Der ukrainische Nationalismus zwischen Stereotyp und Wirklichkeit: $\mathrm{Zu}$ einigen Komplikationenen bei der Interpretation von befreiungs- vs. ultranationalistischen Tendenzen in der modernen Ukraine,' Ukraine-Analysen 107 (2012), accessed August 11, 2014, http://www.laender -analysen.de/ukraine/pdf/UkraineAnalysenı7.pdf; Andreas Umland, 'Challanges and promises of comparative research into post-Soviet fascism: Methodological and conceptual issues in the study of the contemporary East European extreme right,' Communist and Post-Communist Studies 48, no.2-3 (2015):169-181, accessed July 28, 2015, http://dx.doi .org/10.1016/j.postcomstud.2015.07.002 .Whereas the characterization of the oun at this time as fascist is accepted by a growing number of historians in the field, Oleksandr Zaitsev has attempted to revive a historical dichotomy between 'integral nationalism' and 'fascism', introducing the term 'Ustashism' to categorize oun ideology. Oleksandr Zaitsev, 'Fascism or Ustashism? Ukrainian Integral Nationalism in Comparitive Perspective, 1920s-1930s,' Communist and Post-Communist Studies 48, no. 2-3 (2015): 183-193.

23 Vozhd', Leader, was the term used to refer to Konovalets'. After the 1940 split the term was used primarily by the $\operatorname{oun}(\mathrm{m})$ to refer to their leader, whereas the oun $(\mathrm{b})$ referred to theirs as the Providnyk. Rossoliński-Liebe, Stepan Bandera, 180, 548-549.

24 Melnyk assured, in a May 2, 1939 letter to Joachim von Ribbentrop that his organization shared the Weltanschaaung of the National Socialists and Fascists, and offered to help in the 'reorganization' of Eastern Europe. The Archive of the Auswärtiges Amt, PA AA, R 104430, Po. 26, No. 1m, Pol.V. 4784, p. 2. Thanks to Ray Brandon for this reference. Stets'ko's June 30, 1941, declaration of Ukrainian statehood included a statement that the new polity would 'cooperate closely with National Socialist Greater Germany .... under the Führer Adolf Hitler.' Stets'ko assured Hitler, Mussolini, Franco and Pavelić the loyalty of his state to the new Europe. Volodymyr Serhiichuk, ed., OUN-UPA v roky viiny: novi dokumenty i materialy (Kyiv: Vydavnytstvo khudozhnoi literatury ‘Dnipro', 1996), 239; Grzegorz RossolińskiLiebe, 'The "Ukrainian National Revolution" of 1941: Discourse and Practice of a Fascist Movement,' Kritika: Explorations in Russian and Eurasian History 12, no. 1 (2011): 99. 
Rosenberg's office indicated some sympathy for the aspirations of the oun. Hitler's war aims, however, did not include vassal states in formerly Soviet territories, and Germany rejected the oun(b)'s invitations for an alliance with the Ukrainian state, hastily declared by Bandera's deputy Stets'ko in L'viv on June 30, 1941, in the wake of Barbarossa.

\section{Who was Roman Shukhevych?}

Like Stepan Bandera, Roman Shukhevych's person is associated with a number of myths and legends. Shukhevych became active in nationalist radicalism as an adolescent. As a teenager he was already involved in assassination plots against Polish officials in response to the assimilatory policies of the Polish government. He committed his first political murder, that of the Lwów school curator Stanisław Sobiński, at the age of nineteen in $1926 .{ }^{25}$ In 1934, Shukhevych was arrested for his involvement in the murder of Bronisław Pieracki, the Polish minister of the interior, and spent two and a half years in prison, where he was allegedly tortured by the Polish authorities. ${ }^{26}$ Throughout the 1930s, the oun stepped up its campaign of political terrorism against the Polish state, assassinating Polish politicians and political opponents. ${ }^{27}$ At least sixty-three persons were murdered by the oun in interwar Poland. ${ }^{28}$ The Polish authorities responded with a campaign of 'pacification' against the oun, including raids in 494 villages in eastern Galicia. ${ }^{29}$

25 Grzegorz Rossoliński-Liebe, 'Erinnerungslücke Holocaust: Die ukrainische Diaspora und der Genozid an den Juden,' Viertelsjahrhefte für Zeitgeschichte 62, no. 3 (2014): 421.

26 P. Sokhan and P. Potichnyi, ed., Litopys' UPA. Nova seriia, tom 10: Zhyttia i borot'ba henerala 'Tarasa Chuprynky (1907-1950): Dokumenty i materialy (Kyiv and Toronto: Litopys UPA, 2007), 16-17; Vasyl' Kuk, Heneral-khorunzhyi Roman Shukhevych: Holovnyi komandyr Ukrainskoi povstans'koi armii, vydannia druhe, dopovnene (L'viv: Tsentr dolidzhen' vyzvol'noho rukhu, 2007), 22.

27 Lucyna Kulińska, Dziatalność terrorystyczna i sabotażowa nacjonalistycznych organizacji ukrainśkich w Polce w latach 1922-1939 (Krakow: Fundacja Centrum Doumentacji Czynu Niepodległościowego, Księgarnia Akademicka, 2009), 207-302; Alexander J. Motyl, 'Ukrainian nationalist political violence in inter-war Poland, 1921-1939,' East European Quarterly 19, no. 1 (1985): 5 o.

28 Grzegorz Motyka, Ukraińska partyzantka 1942-1960: Dziatalność Organizacji Ukraińskich Nacjonalistów i Ukraińskiej Powstańczej Armii (Warsaw: Instytut Studiów Politycznych PAN, Oficyna Wydawnicza Rytm, 2006), 34-74.

29 Timothy Snyder, Sketches from a Secret War: A Polish Artist's Mission to Liberate Soviet Ukraine (New Haven, NJ: Yale University Press, 2005), 76. 
In January, 1938, Shukhevych crossed the border from Poland to Carpathian Ukraine in Czechoslovakia, which, according to his son Iuryi became his new political base. From there, he often traveled on missions to Prague, Vienna, Berlin, and illegally across the border to Lwów in Poland. ${ }^{30}$ In the spring and summer of that year, according to some sources, he was educated as an officer at a German Military Academy in Munich. ${ }^{31}$ From May to September, 1940, Shukhevych joined over 120 other Ukrainian nationalists for training at a secret Abwehr espionage school in Zakopane, which by then was German-occupied Poland. ${ }^{32}$

After the oun split, Shukhevych belonged to the inner circle of its leadership around Stepan Bandera, and played a key role in organizing the II Velykyi Zbir [Second Congress] of the Bandera Wing of the oun, held in Cracow in April, $1941 .{ }^{33} \mathrm{He}$ was one of the authors of the oun(b) blueprint for action for 1941, Borot'ba i diialnist' oun (b) pid chas viiny [Struggle and Activities of the oun(b) at Times of War], outlining the establishment of a totalitarian state through the indiscriminate use of violence, urging the removal of all 'nonUkrainians' living on Ukrainian territory and the liquidation of 'Polish, Muscovite, and Jewish activists. ${ }^{34}$

$30 \quad$ Iuryi Shukhevych, 'Komandyr bezimennykh,' Ukraina moloda: shchodenna informatsiinopolitychna hazeta, June 24, 2007, accessed December 5, 2007, http://www.umoloda.kiev. ua/print $/ 84 / 45 / 34292 /$.

31 Alexandr Feldman, 'Thirty Years After the Death of Roman Shukhevych,' Contact 2-3 (1980): 77; Mykola Posivnych, 'Roman Shukhevych (30.VI.1907-5.III.1950),' in Litopys Ukrains'koï Povstans'koi Armii. Tom 45: Heneral Roman Shukhevych - 'Taras Chuprynka' Holovnyi Komandyr UPA, ed. Petro J. Potichnyj and Mykola Posivnych (Toronto and L'viv: Vydavnytstvo Litopys UPA, 2007), 28; Anatolii Kentii and Volodymyr Lozyts'kyi, 'From Uvo fighter to supreme commander of the UPA,' Litopys UPA. Nova seria, Tom 10: Zhyttia i borot'ba henerala 'Tarasa Chuprynky' (1907-1950): Dokumenty i materialy, ed. P. Sokhan' and P. Potichnyj (Kyiv and Toronto: Litopys UPA, 2007), 86. What is probably meant is Abwehr training at the Munich Kriegsschule.

'Protokol doprosa osuzhdennogo BIZANTsA Al'freda Ioganovicha ot 23 noiabria 1949 goda,' HDA SBU f. 65, spr. S-7448, ark. 15-22, published in Volodymyr Serhiichuk, ed., Roman Shukhevych u dokumentakh radians'kykh orhaniv derzhavnoi bezpeky (1940-1950), Tom II (Kyiv: PP Serhiichuk, 2007), 383; Karel C. Berkhoff, Harvest of Despair: Life and Death in Ukraine under Nazi Rule (Cambridge, MA: The Belknap Press of Harvard University Press, 2004), 289, 298. On the Zakopane training camp, see Jeffrey Burds, The Early Cold War in Soviet West Ukraine, 1944-1948 (Pittsburgh: The Center for Russian and East European Studies, University of Pittsburgh, 2001), 68.

33 Petro Duzhyi, Roman Shukherych - polityk, voin, hromadianyn (L'viv: Halyts'ka vydavnycha spilka, 1998), 57-6o.

34 'Borot'ba i diial'nist' oun pid chas viiny,' Tsentral'nyi Derzhavnyi Arkhiv Vyshykh Orhaniv Vlady Ukrainy (henceforth TsDAVOU), f. 3833, op. 2, spr. 1, ark. 77-89; Ivan Patryliak, 
Prior to the invasion of the Soviet Union, German military intelligence set up two small Ukrainian formations: Sonderformation Nachtigall, and Organisation Roland. Formed in Cracow on March, 2, 1941, the Nachtigall battalion consisted mostly of Ukrainian Nationalists. Established for the purpose of the immanent attack on the Soviet Union, its members received their training at Neuhammer, Silesia. Its volunteers bore German uniforms and weapons, and were attached to the 1st Battalion of the Regiment Brandenburg-80o. ${ }^{35}$ Shukhevych not only became the highest-ranking Ukrainian officer in the Nachtigall battalion; he also enjoyed the greatest standing among its Ukrainian members.

In the field, Nachtigall was a mixed unit with three companies, each made up of one German platoon and two Ukrainian platoons. A fourth company appears to have been employed in small groups elsewhere. All Ukrainian officers had German doubles, in the case of Shukhevych, it was Theodore Oberländer $\left(1905^{-1998)}{ }^{36}\right.$ Shukhevych, as the ranking Ukrainian, probably conveyed battalion orders to the Ukrainian men of the unit. He received the orders from Hans Albrecht Herzner (d. 1942), Nachtigall's military commander. Herzner, in turn, took his orders from the leadership of the First Battalion of Regiment 80o. When the unit was rounded out with Herzner and the German platoons, Oberländer served as liaison between Nachtigall and Regiment 800 on one hand, and between Nachtigall and Abwehr II Headquarters in Cracow (before the invasion) and the military intelligence department of Army Group South (following the invasion).

Shukhevych's role was that of a courier of orders and a company commander. He was an efficient, but harsh officer, who did not hesitate to use physical violence against his own men. ${ }^{37}$ Nachtigall participated in the invasion of the

Viis'kova diial'nist' oun(b) u 1940-1942 rokakh (Kyiv: NAN Ukrainy, 2004), 128, citing TsDAVO Ukrainy, f. 3833, op. 2, spr. 1; TsDAVO Ukrainy f. 3833, op. 1, spr. 9, ark. 1.

Bolianovs'kyi, Ukrains'ki viis'kovi formuvannia, 66, 571. The Ukrainian nationalist historiography usually refers to Roland and Nachtigall as the Druzhyny Ukrains'kykh Natsionalistiv [DUN; Units of Ukrainian Nationalists], to give the impression that they constituted autonomous units. Bruder, 'Den ukrainischen Staat erkämpfen oder sterben!', 130-132.

36 Philipp-Christian Wachs, Der Fall Theodor Oberländer (1909-1998): Ein Lehrstück deutscher Geschichte (Frankfurt: Campus-Verlag, 2000), 55-71.

37 One of its former members, Viktor Kharkiv (Khmara) described physical abuse at the hands of Shukhevych after having gone to the barber without Shukhevych's explicit permission. 'He attacked me on the spot, asked me how I could have managed to get out, depite the curfew regarding leaving the sealed-off area around the casern. I began explaining that I had only been to the barber. Captain Shukhevych did not listen to that and punched me in the face.' TsDAVO Ukrainy, f. 3833 , op. 1, spr. 57, ark. 18. 
Soviet Union in June, 1941, and took part in the capture of L'viv, Zolochiv, Ternopil' and Vinnytsia. ${ }^{38}$

Before retreating from the advancing German forces, the NKVD massacred many of the inmates it held in prisons across western Ukraine. ${ }^{39}$ Among the thousands of people murdered was Shukhevych's brother. ${ }^{40}$ The NKVD murders radicalized local sentiment, and was instrumentalized by the German forces and local nationalists to incite violent anti-Jewish pogroms. Roman Shukhevych personally helped set up the Ukrainian nationalist militia, which played a key role in the L'viv pogrom. ${ }^{41}$ Soldiers of Nachtigall partook in the July 1, 1941 L'viv pogrom as well as massacres of Jews in the vicinity of Vinnytsia. $^{42}$ The German refusal to accept the oun(b)'s proclamation of Ukrainian

38 According to the protocols of the 1949 interrogation of Alfred Bizanz, the marching route of the unit was L'viv-Ternopil'-Proskurov-Vinnytsia. 'Protokol doprosa osuzhdennogo BIZANTSA Al'freda Ioganovicha ot 23 noiabria 1949 goda,' HDA SBU f. 65, spr. S-7448, ark. 15-22, published in Serhiichuk, Roman Shukherych u dokumentakh radians'kykh orhaniv derzhavnoi bezpeky (1940-1950). Tom II, 385; 'With the military detachment I went through an entire campaign during the first weeks of the war along the line RadymeIavoriv-L'viv-Proskuriv-Zhmerynka-Brailiv-Vinnytsia,' wrote Ivan Hryn'okh (1907-1994), Nachtigall's military chaplain. Andrii Bolianovs'kyi, 'Ivan Hryn'okh - providnyi diiach ukrains'koho pidpillia,' in Boh i Ukraina ponad use: o. Ivan Hryn'okh, ed. Oleksandr Panchenko (Hadiach: Vydavnytstvo 'Hadiach', 2007), 64-65, citing Tsentral'nyi Derzhavnyi Istorychnyi Arkhiv m. L'viv (TsDIAL) f. 201, op. 46, spr. 2689, ark. 26-28. See also Petro Sodol', 'U rokovyny zahybeli Romana Shukhevycha: Interv'iu z Mykoloiu Lebedem,' Suchasnsist', no. 3 (March 1986): 98-104.

39 Marco Carynnyk, 'The Palace on the Ikva: Dubne, 18 September 1939 and 24 June 1941,' in Shared History - Divided Memory:Jews and Others in Soviet-Occupied Poland, 1939-1941, ed. Elazar Barkan, Elizabeth A. Cole, and Kai Struve (Leipzig: Leipziger Universitätsverlag, 2007), 273-302. The most detailed study estimates the victims of Soviet mass shootings in the prisons of East Galicia during the first week of the war at 7,500-10,00o. Kai Struve, Deutsche Herrschaft, ukrinischer Nationalismus, antijüdische Gewalt: Der Sommer 1941 in der Westukraine (Berlin: De Gruyter Oldenbourg, 2015), 215-216.

40 Struve, Deutsche Herrschaft, 281, 36o; Grzegorz Rossoliński-Liebe, 'Der Verlauf und die Täter des Lemberger Pogrom vom Sommer 1941: Zum aktuellen Stand der Forschung,' Jahrbuch für Antisemitismusforschung 22 (2014) 236; Rossoliński-Liebe, Stepan Bandera, 209.

41 Rossoliński-Liebe, 'Der Verlauf und die Täter', 223.

42 Struve, Deutsche Herrschaft, 354-360, concludes that there are clear indications that members of the Nachtigall battalion took part in violence against Jews in all three L'viv prisons on July 1, but adds that they were but one of the perpetrators, and responsible but for a minor part of the anti-Jewish violence carried out that day. On Nachtigall and the L'viv pogrom, see also Rossoliński-Liebe, 'Der Verlauf und die Täter,' $236-237$. On the L'viv pogrom, see: Struve, Deutsche Herrschaft, 247-432; John-Paul Himka, 'The Lviv Pogrom of 1941: The Germans, Ukrainian Nationalists, and the Carnival Crowd, Canadian Slavonic Papers 53, no. 2-4 (2011): 209-243; Tarik Cyril Amar, The Paradox of Ukrainian 
independence led to a conflict with the leadership of the Nachtigall battalion. On August 13, 1941, it was disarmed and ordered to return from Vinnytsia to Neuhammer in Silesia, from which its members were transported to Frankfurt an der Oder.

\section{Shukhevych in Belarus}

On October 21, 1941, the soldiers were reorganized as the 201st Ukrainian Schutzmannschaft Battalion, consisting of four companies. Shukhevych's rank was that of Hauptmann (captain) of the first company and deputy commander of the Legion..$^{43}$ Even though enrollment was voluntary, of the three hundred

Lviv: A Borderland City between Stalinists, Nazis, and Nationalists (Ithaca and London: Cornell University Press, 2015) 93-101; Sergei Chuev, Ukrainskii Legion (Moscow: Iauza, 2006), 180; Frank Golczewski, 'Die Kollaboration in der Ukraine,' Beiträge zur Geschichte des Nationalsozialismus 19 (2003): 162; Christoph Mick, 'Ethnische Gewalt und Pogrome in Lemberg 1914 und 1941,' Osteuropa 53 (2003): 1810-1811, 1824-1829; Hannes Heer, 'Einübung in den Holocaust: Lemberg Juni/Juli 1941, 'Zeitschrift für Geschichtswissenschaft 49 (2001): 410, 424; Bruder, 'Den ukrainischen Staat erkämpfen oder sterben!', 140-150; Frank Grelka, Die ukrainische Nationalbewegung unter deutscher Besatzungsherrschaft 1918 und 1941/1942 (Wiesbaden: Harassowitz, 2005), 276-286; Dieter Pohl, Nationalsozialistische Judenverfolgung in Ostgalizien 1941-1944: Organisation und Durchführung eines staatlichen Massenverbrechens (München: Oldenbourg, 1997), 60-62; Wachs, Der Fall Theodor Oberländer, 71, 78-80; Eliyahu Yones, Die Straße nach Lemberg: Zwangsarbeit und Widerstand in Ostgalizien 1941-1944 (Frankfurt am Main: Fischer Taschenbuch Verlag, 1999), 18. On the shooting of Jews in the Vinnytsia area, Nachtigall member Viktor Kharkiv (Khmara) later wrote 'At the time of our march eastwards we saw with our own eyes the victims of the Judeo-Bolshevik terror, and the sight of it so strengthened our hatred of the Jews, that in two villages we shot all the Jews we encountered. I recall one example. At the time of our march through one village we saw many vagrant people. Asked where they were going, they answered that the Jews were threatening them and that they were afraid of spending the night in their houses. As a result of that, we shot all the Jews we encountered there.' TsDAVO Ukrainy, f. 3833 , op.1, spr. 57, ark. 17 .

43 Ievhen Pobihushchyi-Ren, Mozaika moikh spomyniv (Ivano-Frankiv'sk: Lileia-HB, 2002), 62. Pobihushchyi, the former commander of the Roland battalion, served as an officer in Schutzmannschaft Battalion 201, and became an officer in the Waffen-ss Division Galizien in 1943. Bolianovs'kyi, Ukraïns'ki viis'koviformuvannia, 6o, 143, 36o; Per A. Rudling, 'Szkolenie w mordowaniu: Schutzmannschaft Battalion 201 i Hauptmann Roman Szuchewycz na Białorusi 1942 roku,' in Prawda Historyczna a Prawda Polityczna w badaniach naukowych: Przyktad ludobójstwa na Kresach potudniowo-wschodniej Polski w latach 1939-1946, ed. Bogusław Paź (Wrocław: Wydawnictwo uniwersytetu Wrocławskiego, 2011), 183-204. The commanders of the other three companies were Hauptmann Bryhyder, who later continued as an officer in ss Galizien, Vasylyi Sydor and Volodymyr Pavliuk. Haluznyi 
remaining members of the Nachtigall unit, only about fifteen declined to sign up for service in the Schutzmannschaft. ${ }^{44}$ Almost all of its members belonged to the oun. ${ }^{45}$ To the battalion were added sixty Soviet Pows from Poltava and Dnipropetrovs'k districts, selected by Shukhevych. ${ }^{46}$ After training in Germany, Schutzmannschaft Battalion 201 was assigned to Belarus on February 16, 1942. The soldiers signed a one-year contract with the Germans. ${ }^{47}$ The men of Schutzmannschaft Battalion 201 wore German Order Police field uniforms without national symbols. On March 16, 1942, the battalion arrived in Belarus and was spread out over twelve different points in the triangle Mahiliou-VitsebskLepel', guarding a territory of $2,400 \mathrm{~km}^{2} .48$

Soviet post-war investigations into the unit's whereabouts show that the Soviet authorities were particularly interested in any evidence of Schutzmannschaft Battalion 201 fighting Soviet partisans. The way the interrogators formulated their questions indicates that the Soviet state security organs were more interested in activities they regard as treason and undermining of Soviet government, than atrocities against 'peaceful Soviet citizens.' 'Before the battalion was reassigned to Belarus the fascists gave it the name "Schutzmannschaft Battalion 201," which carried out punitive action against Belarusian partisans, ${ }^{49}$ we read in a statement from 1986 by a former regional leader of the OUN and UPA. Soviet internal records emphasize how, in 1942, 'The Konovalets' Legion [i.e., Nachtigall] was renamed "Schutzmannschaft

Derzhavnyi Arkhiv Sluzhba Bezpeky Ukrainy, Kyiv (Henceforth HDA SBU) f. 5, spr. 67418, t. 1, ark. 208-241, in Roman Shukhevych u dokumentakh radians'kykh orhaniv derzhavnoi bezpeky (1940-1950). Tom I, ed. Volodymyr Serhiichuk (Kyiv: PP Serhiichuk M.I., 2007), 529. Parmen Posokhov, 'Shukhevych: Beloe piatno v biografii,' FRAZA, August 15, 2007, accessed November 18, 2007, http://fraza.org.ua/zametki/15.08.07/40788.html?c=post\&i=113503. On October 15, 1941, in Neuhammer, Silesia Nachtigall had a total of 288 men. In Vienna, Roland counted 210 men at the time.

45 Chuev, Ukrainskii legion, 180; Volodymyr V'iatrovych, 'Roman Shukhevych: soldat,' Ukraïns'ka Pravda, May 2, 2008, accessed May 6, 2008, http://www.pravda.com.ua/news/ 2008/4/25/75222.htm; Pobihushchyi-Ren, Mozaika moikh spomyniv, 115; Bolianovs'kyi, Ukrains'ki viis'kovi formuvannia, 143.

46 Bolianovs'kyi, Ukrains'ki viis'kovi formuvannia, 144; Myroslav Kal'ba, ed., U lavkah druzhynnykiv: Druzhyny Ukrains'kykh Nationalistiv v 1941-1942 rokakh (Vyd-ia Druzhyny ukrainsks'kykh nationalistiv, 1953), 91.

47 Posivnych, 'Roman Shukhevych,' 29.

48 Bolianovs'kyi, Ukrains'ki viis'kovi formuvannia, 183.

49 Statement by former UPA activist and oun military liaison Luky Pavlyshyn. 'Protokol zaiava,' Luky Stepanovych Pavlyshyn, (b. 1907), L'viv, Ukrainian ssr, May 13, 1986, p. 3, Yad Vashem Archives, Record Group 0.32, file number 112, inventory number 99999, number M.37/111. Thanks to Jeffrey Burds for providing a copy of this document. 
Battalion 201" by the Germans and sent to Belarus, where it partook, along with a German punitive detachment, in the struggle with Soviet partisan detachments, and the protection of German military objects. 50

Interrogated by the Soviet authorities in November, 1949, Alfred Bisanz (1890-1951), ${ }^{51}$ the liaison for Ukrainian matters in Hans Frank's Generalgouvernment who retained unofficial contacts with the Ukrainian nationalists throughout the war, recalled Shukhevych having visited his department three times in L'viv during 1942; in February, May, and November. Regarding their May, 1942 meeting, Bizans stated that 'I asked [Shukhevych] about the activities of the Ukrainian battalion at that time. He answered that the battalion takes part in the Germans' punitive operations against Soviet partisans in Belarus. In connection with this, SHUKHEVYCH told me, that his battalion several time got involved in battles against Soviet partisans and had some losses among its men. ${ }^{52}$ As the military situation was deteriorating for the Germans over the course of 1942, Schutzmannschaft Battalion 201 faced problems of desertions. 'In November, 1942, I received SHUKHEVYCH in L'viv in connection with the large number of deserters from the battalion.... SHUKHEVYCH said that his battalion was conducting frequent punitive operations not only against Soviet partisans, but also against the civilian population of Belarus. ${ }^{53}$

Current research points to the intimate link between the 'anti-partisan warfare' of the German forces and their local auxiliaries, and mass violence against the local population in occupied Belarus. Waitman Beorn's recent study on the German military and the Holocaust in Belarus demonstrates a staggering disproportionality between German and 'partisan' losses, and notes that the label 'partisan' was a very wide concept, which included various non-combatants: former Red Army soldiers separated from their units during the German advance as well as 'suspicious' civilians and unarmed Jewish civilians. ${ }^{54}$

50 'Spravka o prestuplennoi deiatel'nosti ukrainsoi emigratsii vo vremia voiny Germanii s SSSR,' HDA SBU, f. 13, spr. 372, ch. 35, l. 32.

$5^{1}$ For a biography of Bisanz, see Struve, Deutsche Herrschaft, 97.

$5^{2}$ 'Protokol doprose osuzhdennogo BIZANTSA Al'freda Ioganovicha ot 23 noiabria 1949 goda,' HDA SBU f. 65, spr. S-7448, ark. 15-22, published in Serhiichuk, Roman Shukherych u dokumentakh radians'kykh orhaniv derzhavnoi bezpeky (1940-1950). Tom II, 388. Many years later Mykola Lebed recalls having met Shukhevych in Lviv 'in mid-1942', during which they discussed the situation. Sodol, 'U rokovyny zahybeli Romana Shukhevycha,' 99 .

53 'Protokol doprose osuzhdennogo BIZANTSA Al'freda Ioganovicha ot 23 noiabria 1949 goda,' HDA SBU f. 65, spr. S-7448, ark. 15-22, published in Serhiichuk, Roman Shukherych u dokumentakh, Tom II, 388-389.

54 Waitman Wade Beorn, Marching into Darkness: The Wehrmacht and the Holocaust in Belarus (Cambridge, MA: Harvard University Press, 2014), 95. 
Beorn refers to what he calls 'the Jew-Bolshevik-partisan calculus' according to which, 'all Jews were Bolsheviks, all Bolsheviks were partisans, and thus, all Jews were also partisans or partisan supporters. ${ }^{55}$ This formula, Beorn argues, 'is important in explaining the murder of Jews under the guise of anti-partisan war. ${ }^{56}$ Thus, this anti-partisan warfare needs to be understood in the context of genocide. "The Holocaust and the anti-partisan war have long remained separated in the historiography, with anti-Jewish actions inhabiting the history of Nazi genocide and the anti-partisan war the military history of the war on the eastern front. This is a false division. ${ }^{57}$ Beorn points out that from August to December, 1941, 'roughly 30 partisans [were] killed for every German,' noting how this "hardly indicate[s] a vibrant and dangerous insurgency.58

This contextualization is helpful for assessing the activities of the Schutzmannschaft Battalion 201. During its ten-month deployment in Belarus, the battalion lost forty-nine men, and forty of its members were wounded. At the same time, it killed over two thousand 'partisans'.59 Even if all the battalion's losses were due to war deaths, this means a discrepancy in the casualty ratio between Schutzmannschaft Battalion 201 and enemy 'bandits' of over 1:40. ${ }^{60}$ The report of the activities of the battalion for October 30,1942 , by ssObergruppenführer Erich von dem Bach-Zelewski (1899-1972), the commander of the so-called Bandenkämpferverbände, or 'bandit-fighting units', appears in a folder of fifteen reports on counterinsurgency activities (titled Meldungen an den Führer über Bandenbekämpfung), addressed to Reichsführer-ss Heinrich Himmler, who in turn passed them to Adolf Hitler personally. ${ }^{61}$ Report number 51, summarized the anti-partisan activities in Russia-South, Ukraine, and the Białystok area from September to November, 1942. Passed to Hitler on December 29, 1942, this report lists a ratio of killed Schutzmänner and Germans

\footnotetext{
55 Beorn, Marching into Darkness, 95.

56 Ibid.

57 Ibid., 118

58 Ibid., 95 .

59 I. K. Patryliak, Viiskova diial'nist oun (b) u 1940-1942 rokakh (Kyiv: Kyivs'kyi natsional'nyi universytet im. Tarasa Shevchenko, Instytut istorii Ukrainy NAN Ukrainy, 2004), 386.

$60 \quad$ Rudling, 'Szkolenie w mordowaniu,' 203.

61 Meldung Nr. 36, 'Ergebnisse im Gebiet Russland Mitte. Gefecht des SchutzmannschaftsBatallions 201, 20km nördlich Lepel, Feld-kommandostelle Nov. 3, 1942,' Records of the Reich Leader of the ss and Chief of the German Police [Reichsführer-ss und Chef der deutschen Polizei], United States National Archives and Records Administration (henceforth NARA), EAP T-175, item 161-b-12/250, reel 124, frame 2599081; and Philip W. Blood, Hitler's Bandit Hunters: The ss and the Nazi Occupation of Europe (Washington, DC: Potomac Books, 2006), 90-91.
} 
to 'bandits' and 'bandit helpers' (excluding the category of 'Executed Jews') of over 1:52. If we were to include the 363,211 executed Jews, listed as 'suspected bandits', the ratio would be $1: 843 .{ }^{62}$ The reports for autumn of 1942 for RusslandMitte and Gebiet Weissruthenien similarly report 28,36o enemy losses, but only 381 'own losses,' a ratio 1:74. ${ }^{63}$ The staggering disproportionality in the number of casualties provides a troubling context in which Schutzmannschaft Battalion 201 and other anti-partisan auxiliaries under von dem Bach's command operated in occupied Belarus in late 1942. As the partisan war escalated in Belarus over the course of that year, the occupiers responded with indiscriminate use of violence against the civilian population, with Baltic and Ukrainian Schutzmannschaften being central to implementation of the brutal pacification. The incomplete source base for Schutzmannschaft Battalion 201 strongly suggests that this also unit - like other Schutzmannschaft battalions- was involved in brutal 'anti-partisan' counterinsurgency measures that targeted civilians, equating Jews with partisans. The extreme disproportionality in terms of losses supports Bisanz's testimony that also the 2o1st battalion, similar to other Schutzmannschaften active in Belarus in 1942-43, disproportionally targeted the civilian population.

\section{From Schutzmannschaften into the UPA}

As the German Sixth Army was getting trapped in Stalingrad, the oun(b) leadership was forced to reassess the situation, and was slowly abandoning its proGerman orientation, as Tarik Amar has noted, 'at first reluctantly and never completely.' 64 'As long as the struggle against the Soviets continued, the oun-B argued, "our political reason tells us to bide our tine," meaning to avoid confrontation with the Germans. ${ }^{\prime 65}$ Acting ouv(b) leader Mykola Lebed (1909-1998) opposed taking up armed attacks on German interests, as did Shukhevych. ${ }^{66}$ Local initiatives, such as the repeated requests from UPA-North to take up arms

\footnotetext{
62 Reichführer-ss Chef der Deutschen Polizei, Meldungen 35, 36, 37, 38, 40, 41, 42, 45, 46, 47, 48, 49, 51, 55, and 56, issued Nov. 3, 1943 to Jan. 17, 1943: NARA MF-3293, T-175, roll 124.

63 Rudling, 'Szkolenie w mordowaniu,' 204.

64 Tarik Cyril Amar, 'A Disturbed Silence: Discourse on the Holocaust in the Soviet West as am Anti-Site of Memory,' in The Holocaust in the East: Local Perpetrators and Soviet Responses, ed. Michael David-Fox, Peter Holquist and Alexander M. Martin (Pittsburgh: University of Pittsburgh Press, 2014), 169 .

65 Ibid.

66 Interrogation of Mykailo Stepaniak, HDA SBU, f. 6, d.1510.tom 1, ll. 61 and 71-72.
} 
against the German forces, were turned down. ${ }^{67}$ Yet, many years after the war, Lebed claimed that it was he who, at the end of 1942, suggested that Shukhevych should transfer the entire Schutzmannschaft Battalion 201 from Belarus to Polissia and Volhynia to 'include it in the struggle against the Germans, as well as the Red partisans,' to which Shukhevych responded, according to Lebed, that he 'would take this into consideration and let me know his decision.' ${ }^{68}$

The men of Schutzmannschaft Battalion 201 had signed a contract of service until December 31, 1942. However, in late 1942 the German authorities unilaterally extended the term of service indefinitely. ${ }^{69}$ When the battalion was ordered back to L'viv in January, 1943, Shukhevych left the unit. ${ }^{70}$ In the spring of 1943, the men of the Schutzmannschaft Battalion 201, who had crossed over from Belarus to Volhynia came to constitute the hard core of the oun (b) security service, the Sluzhba Bezpeki, or sв. ${ }^{71}$ Others stayed and were transferred to the Waffen-ss Galizien. ${ }^{22}$ The men of Schutzmannschaft Battalion 201 who continued their service were transferred to Battalion 57 , which was returned to

67 Report from Soviet agent 'Iaroslav' to the Third Department of Soviet counterintellgence directorate SMERSH, Nov. 23, 1944, HDA SBU, f. 13, sbornik 372, tom 5, l. 25.

68 Sodol,' 'U rokovyny zahybeli Romana Shukhevycha,' 99. Lebed's post-war accounts of the UPA are highly selective and need to be treated with great caution.

69 Martin C. Dean, 'The German Gendarmerie, the Ukrainian Schutzmannschaft and the "Second Wave" of Jewish killings in Occupied Ukraine: German Policing at the Local Level in the Zhitomir Region, 1941-1944,' German History 14, no. 2 (1996): 179.

70 According to Nachtigall veteran Myrosla Kal'ba (1916-2013) and L'viv activist historian Mykola Posivnych (b. 1980), the unit was ordered to L'viv on January 6, and most of its soldiers arrived on January 8. Posivnych, 'Roman Shukhevych,' 29. According to Pobihushchyi, the officers arrived in L'viv on January 5 , and the last of its soldiers left Belarus on January 14, 1943. Ievhen [Pobihushchyi]-Ren, 'Spohady pro generala Romana Shukhevycha,' in U lavkah druzhynnykiv: Druzhyny Ukrains'kykh Nationalistiv v 1941-1942 rokakh, ed. Myroslav Kal'ba (n.p: Vyd-ia Druzhyny ukrainsks'kykh nationalistiv, 1953), 40; Pobihushchyi-Ren, Mozaika moikh spomyniv, 85. The details differ in that pro-nationalist accounts often present it as Shukhevych went underground after an arrest warrant against him was issued; in reality, the sequence of events seems to be the reversed, with an arrest warrant being issued after he broke the unilaterally extended contract.

Ivan Katchanovski, 'The Politics of World War II in Contemporary Ukraine,' The Journal of Slavic Military Studies 27, no. 2 (2014): 220. Other officers of Schutzmannschaft Battalion 201 became officers in the Waffen ss Galizien. HDA SBU, f. 5, spr. 67418, t. 1, ark. 208-241, in Serhiichuk, Roman Shukhevych u dokumentakh, Tom II, 529-530.

72 Andrii Bolianovs'kyi, Dyviziia 'Halychyna': Istoriia (Lviv: A. Bolianovs'kyi, 200o) 61, lists ten Nachtigall Officiers and NCOs and four Roland officers in Waffen-ss Galizien. On the Waffen-ss Galizien, see Per Anders Rudling, "They Defended Ukraine”: The 14. WaffenGrenadier-Division der ss (Galizische Nr. 1) Revisited,' The Journal of Slavic Military Studies 25 , no. 3 (2012): 329-368. 
Belarus where it continued with anti-partisan operations and partook in mass killing over the course of 1943, in particular in connection with the large-scale action against the Belski partisans in the Naliboki Forest. ${ }^{73}$

Together with several thousand Ukrainian policemen who had deserted the Germans, the veterans of Schutzmannschaft Battalion 201 now came to form the backbone of the UPA. From March 15 to April 15, 1943, close to four thousand Ukrainian former Schutzmänner joined the ranks of the UPA. ${ }^{74}$

73 'Mit'ko i drugikh,' HDA SBu f. 5, delo 65509, tom 5, l. 361 . Page 331 of this file contains a list of 50 men from Schutzmannschaft Battalion 201 transferred to Schutzmannschaft Battalion 57 following the dissolution of the former. See also: SBU f. 5 , delo 65509, tom 3, ll. 261-262. Within the ranks of Schutzmannschaft Battalion 57 many former members of the 201 Battalion took part in the burning of the villages of Pochatovo and Zatareshch in the Naliboki forest to the ground; destroying thirty-four houses in the village of Goridishki; abducting civilians from the village of Zastarenia for forced labor in Germany; burning, in their entirety, the villages of Iatry and Zatop'e; as well as destroying thirty-six houses in Zazhokhe. They took part in the shooting of Jews and forced forty-six people into the dusheguby, 'soul killers', i.e. portable gas vans. The men of Schutzmannschaft Battalion 57 took part in burning the entire village of Gorodishche in the Baranovichi District, where the residents were accused of aiding the partisans. Men, women, elderly, and children were chased into a house, where they were burnt alive. They grabbed children by the legs and smashed them to death against the corners of the house, throwing their little bodies into the fire, in which the adults were immolated alive. Those trying to escape were mowed down by machine gun fire. In all, 124 houses were burnt, 360 people - men, women, and children killed. In Pochaiov fifty-six houses were burnt, seventeen people killed; in the village of Iatra seventy-five houses, five people murdered; in Zapol'e thirtysix houses, seven persons killed. 'Mith'ko i drugikh' HDA SBU f. 5 , delo 65509, tom. 4, ll. 7, 12, 18, 19, 20, 30, 39, 43, 65, 74, 76, 78, 79-96, 105, 114, 117, 118, 121, 128, 131-131, 143, 174, 179, 184. Schutzmänner Derikh and Pelikh were sentenced to death and executed on June 29, 1945. They were denied legal rehabilitation on December 25, 2000. HDA SBU, f. 5, delo 65509, t.5, l. 336. For the complete statement of its members: HDA SBU f. 5 , delo 65509, tom 5 , ll. 33-120. A summary appears in connection with the rejected rehabilitation in 2000: HDA sBU f. 5, delo 65509, tom 5, ll. 350-390. On the Belski partisans, see: Nechama Tec, Defiance (Oxford: Oxford University Press, 2009) and Peter Duffy, The Bielski Brothers: The True Story of Three Men Who Defied the Nazis, Built a Village in the Forest, and Saved 1,200 Jews (New York: Harper Collins Publishers, 2004).

74 Volodymyr Serhiichuk, ed., Roman Shukhevych u dokumentakh padians'kykh orhaniv derzhavnoï bezpeky (1940-1950). Tom I (Kyiv: PP Serhiichuk M.I., 2007), 11. The most detailed works to date on local perpetrators in Volhynia are: Jared Graham McBride, “A Sea of Blood and Tears": Ethnic Diversity and Mass Violence in Nazi-Occupied Volhynia, Ukraine, 1941-1944' (Ph.D. thesis, Ucla, 2014); Jared McBride, 'Peasants into Perpetrators' (forthcoming, Slavic Review); Jared McBride, Contesting the Malyn Massacre: The Legacy of Inter-Ethnic Violence and the Second World War in Eastern Europe (Pittsburgh: The Center for Russian and East European Studies, University of Pittsburgh, 2016). 
They applied the skills acquired in 1941-1942 for carrying out systematic massacres of the civilian Polish population in the massacres against the civilian Polish population in 1943 and $1944 .{ }^{75}$ Schutzmannschaft Battalion 201, in particular, became an important nursery for future UPA commanders. Other than Shukhevych himself, its alumni included Oleksandr Luts'kyi, the organizer and first Commander of the UPA-West, based mainly in Galicia, and Vasyl Sydor, Commander of UPA-West from 1944 to $1949 .^{76}$

According to several accounts, acting oun(b) leader Mykola Lebed' issued orders in April, 1943 to cleanse the 'entire revolutionary territory' of Poles. ${ }^{77}$ Yet, on April 13,1943, Lebed was replaced by a triumvirate, in which Shukhevych was 'the first among equals. ${ }^{78}$ Shukhevych consolidated his position in both the UPA and the oun (b), which appointed him commander of the UPA in August $1943 .{ }^{79}$ The massacres of the Volhynian Poles appear to have been initiated somewhat earlier, in February, 1943, on a local initiative by the commander of UPA-North, Dmytro Kliachkivs'kyi (1911-1945), nom de guerre 'Klym Savur'. Shukhevych endorsed Savur's methods and expanded them to other territories under UPA control. The campaign reached its climax in July, $1943 .{ }^{80}$ The most detailed studies of the OUN-UPA mass murders of Poles estimates the oun and UPA's Polish victims to range between 70,000 and 100,000, their Jewish victims in the thousands. ${ }^{81}$

75 Timothy Snyder, The Reconstruction of Nations: Poland, Ukraine, Lithuania, Belarus, 1569-1999 (New Haven: Yale University Press, 2003), 162.

76 Petro Sodol, Ukrains'ka povstancha armiia, 1943-1949: Dovidnyk (New York: Proloh, 1994).

77 Timothy Snyder, 'The Causes of Ukrainian-Polish Ethnic Cleansing 1943,' Past and Present, no. 179 (2003): 202; Taras Bul'ba-Borovets', Armiia bez derzhary: Slava i trehediia ukrains'koho povstans'koho rukhu. Spohady (Kyiv: Knyha Rodu, 2008), 250-266. Petro Balei, Fronda Stepana Bandery v oun 1940 roku (Kyiv: Tekna, 1996), 141.

78 Motyka, Ukrainska partyzantka, 117; Kentii and Lozyts'kyi, 'From uvo Fighter to Supreme Commander of the UPA,' 98-99; David R. Marples, Heroes and Villains: Creating National History in Contemporary Ukraine (Budapest and New York: Central European University Press, 2007), 195.

79 Kentii and Lozytskyi, 'From uvo Fighter to Supreme Commander of the UPA,' 99.

8o Motyka, Ukrainska partyzantka, 366-367. Extract from a record of the interrogation of Mykhailo Stepaniak, regarding the third conference of the oun held in February 1943. Note 'From the reflections of an elderly oun member,' HDA SBU, f. 13, spr. 376, t. 34, p. 268, reprinted in J. Bednarek, ed., Poland and Ukraine in the 1930s and 1940s (Warsaw: Institute of National Remembrance, 2009), 407; 'Protokol doprosa obviniaemogo Stepaniaka Mikhaila Dmitrievicha ot 25 avgusta 1944 goda,' HDA SBU, f. 13, spr. 372, t. 1, k. 21-59, Pol'shcha ta Ukraina u trydtsiatykh-sorokovykh rokakh XX stolittia, 230.

81 Ewa Siemaszko, 'Stan badań nad ludobójstwem dokonanym na ludności polskiej przez Organizację Nacjonalistów Ukraińskich i Ukraińską Powstańczą Armię,' in Prawda Historyczna a Prawda Polityczna w badaniach naukowych: Przykład ludobójstwa na Kresach potudniowo-wschodniej Polski w latach 1939-1946, ed. Bogusław Paź (Wrocław: 
In the pro-nationalist rendering of history, the oun's collaboration with Nazi Germany, the anti-Jewish pogroms, and the massacres of the Polish minority in Volhynia and eastern Galicia are ignored, glossed over, or outright denied. The period from August, 1941, to January, 1943, is either downplayed or omitted from most Shukhevych biographies, the focus instead being heavily centered on Shukhevych's role, from 1943 until his death in 1950, as commander of the UPA, the largest armed national resistance in the Soviet Union. Shukhevych's defiant resistance to Stalinism has a powerful appeal to the patriotic imagination of many Ukrainians, particularly in the western part of the country. However, as Shukhevych was turned into an official hero of Ukraine and the organization he led presented as representing the Ukrainian people, questions also emerged in regards to the 'missing years,'omitted from the hagiographies.

The assessment of Shukhevych's whereabouts in Belarus differ sharply. If University of Hamburg historian Frank Golczewski describes the activities of Schutzmannschaft Battalion 201 as 'fighting partisans and killing Jews, ${ }^{82}$ in Litopys Ukrains'koi Povstans'koi Armii [The Chronicle of the Ukrainian Insurgent Army], a massive undertaking by the UPA veterans to establish a positive history of their organization, we read: 'In taking direct part in battles against the Belarusian partisans and studying the Nazis' anti-partisan operations, Shukhevych not only acquired combat experience but also absorbed the rules of partisan warfare. In our opinion, he became one of the finest adepts of this specific form of armed struggle in the ranks of the Ukrainian liberation movement.'83

\section{Heroic representations of Shukhevych}

Since the early 1950s the figure of Shukhevych as a hero and martyr has been central to the identity of the Ukrainian diaspora. ${ }^{84}$ In 2007 , on the centennial of

Wydawnictwo uniwersytetu Wrocławskiego, 2011), 341; Motyka, Ukraińska partyzantka, 410-412, 649-650; Grzegorz Hryciuk, Przemiany narodowościowe i ludnościowe w Galicji Wschodniej i na Wotyniu w latach 1931-1948 (Toruń: Wydawnytswo Adam Marszałek, 2005), 281; John-Paul Himka, 'The Ukrainian Insurgent Army and the Holocaust,' paper prepared for the 41st national convention of the American Association for the Advancement of Slavic Studies, Boston, November 12-15, 2009.

82 Golczewski, 'Die Kollaboration,' 176.

83 Kentii and Lozytskyi, 'From uvo Fighter to Supreme Commander of the UPA,' 94. Initiated and edited by UPA veterans and funded by the CIA until 1991. On the CIA funding of Litopys UPA, see: 'Renewal of Operational Activity" from A IAD/SE G/IB,' January 24, 1983, p. 2, NARA, QRPLUMB, vol. 4, RG 263, box 59, NN3-263-02-008.

84 After the Second World War, hundreds of thousands of Ukrainians found themselves in exile. In emigration, they established their own organizations, parties, institutions, and 
Shukhevych birth, the editors of the Litopys Ukrains'koi Povstans'koi Armii published two massive volumes 'dedicated to the glorious memory' of Shukhevych. Volume 45 of the Litopys remains largely silent on Shukhevych's whereabouts in 1942, deliberately avoiding the word Schutzmannschaften. Shukhevych is presented as the man who 'in the late 1940s headed the struggle against the two largest totalitarian regimes in the world - the Soviet Union and Nazi Germany .... In these memoirs this celebrated military-political figure, leading member of the OUN, and commander in chief of the UPA is portrayed as a brilliant student, athlete, musician, military man, politician, and businessman. ${ }^{85}$ The account of his whereabouts from fall 1941 to early 1943 is short:

In August the Legion was removed from the front, its members interned and then transferred to Germany. Here the Ukrainian soldiers reorganized themselves into Defensive Battalion No. 201, and in keeping with a separate contract were compelled to agree to an additional year of service. On 16 March 1942 the battalion was deployed to Belarus, to the vicinity of the town of Borovka, to protect military installations and fight Soviet partisans. After one year of service all the soldiers, led by Shukhevych, refused to continue serving. On 6 January 1943 they were sent under guard to L'viv, where they arrived on 8 January 1943. Shukhevych, who knew that all of the officers would be arrested, slipped away from the Gestapo and disappeared. ${ }^{86}$

Volume 10 of the New Series of Litopys UPA is a little more elaborate, alluding to atrocities in Belarus, but that Shukhevych managed to maintain human decency:

The struggle against the partisans in Belarus was difficult and exhausting, and the laurels of victory did not fall to either the Germans or their allies, including the soldiers of the Ukrainian police battalion. According to $\mathrm{V}$. Ianiv, 'this was a horrible time' in Shukhevych's life, who was forced 'to play the role of the Germans' friend to the last minute' although 'his heart was breaking from pain.' Myroslav Kal'ba recalls that Shukhevych and other Ukrainian commanders sought to avoid taking part in the Nazis'

educational networks. From around 1980, they started to refer to themselves as a diaspora, rather than as émigrés.

85 Petro J. Potichnyj and Mykola Posivnych, ed., Litopys Ukrains'koi Povstans'koi Armii, Tom 45, Heneral Roman Shukherych - 'Taras Chuprynka' Holovnyi Komandyr UPA (Toronto and L'viv: Vydavnytstvo Litopys UPA, 2007), 522. 
punitive actions against the local population and tried to evade the food requisitions, declaring 'that we were sent here to fight, not loot.'

In taking direct part in battles against the Belarusian partisans and studying the Nazis' anti-partisan operations, Shukhevych not only acquired combat experience but also absorbed the rules of partisan warfare. In our opinion, he became one of the finest adepts of this specific form of armed struggle in the ranks of the Ukrainian liberation movement. ${ }^{87}$

Mykola Posivnych's introduction to volume 45 concisely articulates the traditional diaspora view:

Roman Shukhevych occupies an exceptional place in the twentieth century pantheon of Ukraine's national warriors. He was one of the organizers of the struggle against all occupiers of Ukraine .... The life and deeds of the commander in chief of the UPA, Brigadier-General Roman Shukhevych - 'Taras Chuprynka' - are a shining example of the heroic struggles for Ukrainian statehood and should serve as a model to be emulated by future generations of Ukrainians. ${ }^{88}$

Shukhevych is referred to as 'a beacon that shows the path for the young generation,' and his service in Belarus as 'a great example of heroic character, the highest ethical values, national honor, and Christian morality.' 89

\section{Shukhevych as Hero on the Silver Screen}

Iziaslav Kokodniak, writing in the nationalist newspaper Za vil'nu Ukrainu in 2000, argued that the Ukrainian people needs to be nationally conscious, and that the Ukrainian state must become national in content. He explicitly called for the dissemination of 'nationalist myths' to counter Soviet myths on the crimes of UPA. Nationalist organizations, according to Kokodniak, must

87 Kentii and Lozytskyi, 'From uvo Fighter to Supreme Commander of the UPA,' 93-94. The Litopys remains less than forthcoming with information which does not conform with the aim to promote the UPA commander. O. Ishhuk and S. Kokin, in Litopys UPA. Nova seria, Tom 10: Zhyttia i borot'ba henerala 'Tarasa Chuprynky' (1907-1950): Dokumenty i materialy, ed. P. Sokhan' and P. Potichnyj (Kyiv and Toronto: Litopys UPA, 2007), 329, omits a section in which it is noted that 'Bandera has a low opinion of Shukhevych.' Jeffrey Burds, 'Archival Practices in the Post-Soviet Zones,' paper presented at the 2008 National Convention of the American Association for the Advancement of Slavic Studies, Philadelphia, November 23, 2008.

88 Posivnych, 'Roman Shukhevych,' 19, 33.

89 Potichnyj and Posivnych, Litopys Ukraïns'kö̈ Povstans'koï Armiï, Tom 45, 361. 
'impose their will' on the state and mass media. Shukhevych, Kokodniak argues, would be an ideal instrument for the construction of a new nationalist myth. ${ }^{90}$ One example of this is Oles' Ianchuk's motion picture Neskorenyi [The Undefeated] from 2000. The movie introduces Shukhevych as:

a genteel family man forced by brutal circumstances and his own sense of duty to lead the fight to deliver his people from the savageries of both the Nazis and Soviets.... Yanchuk explores the complex character of Shukhevych, his revulsion at ethnic discrimination, his love of music, his genius in combat. The film smolders with the passion of the man and ignites that viewer with the same fire that Shukhevych fueled in his countrymen - the unquenchable flame of freedom .... It is a personal story of faith and commitment and ultimately, the victory over tyranny. ${ }^{91}$

Ianchuk portrays Shukhevych as a valiant hero, something of a combination of George Washington and James Bond: a remarkably handsome man, always surrounded by young, attractive females, yet ever faithful to his wife and family. Shukhevych's attitude to the Germans is portrayed as defiant, even domineering. His German superiors tremble in his presence, speaking in a soft and hesitant voice, avoiding eye contact as Shukhevych, in a loud voice demands the release of Bandera and declares his loyalty to Ukraine, not Hitler or Germany. This is followed by a battle scene in which the hero overpowers his German captors on a train, and discreetly departs into the majestic nature of the Carpathian Mountains just as the leaves are turning. The viewer gets the impression of a clean break with the Germans in the fall of 1941 and that Shukhevych thereafter pursued an active armed resistance against both the Nazis and the Soviets. The hero dramatically sheds his German uniform as a voice announces in first person: 'I left the Wehrmacht, earlier than we had anticipated. The oun went into the deep underground. The Hitlerite terror forced the leadership to establish self-defense forces. Thus, the Insurgent Army developed into a regular army.'

The movie then makes a hefty jump forward in the chronology. The period between July, 1941, to August, 1943, during which the bulk of the Ukrainian Jews were murdered and the fortunes of the Germans turned, are simply omitted. Left out are also UPA's massacres of tens of thousands of Volhynian Poles during the summer of 1943 , while Shukhevych headed the organization. ${ }^{92}$ The

\footnotetext{
$90 \quad$ Marples, Heroes and Villains, 261.

91 'The Undefeated (Neskorenyi),' Metro Cinema, accessed April 17, 2008, http://www .metrocinema.org/film_view?FILM_ID=1663.

92 Ihor Ivanovych Il'iushyn, Volyns'ka trahediia 1943-1944 rr (Kyiv: Instytut istoriï Ukraïny NAN Ukrainy, 2003), 198.
} 
viewer is re-introduced to the historical narrative only in autumn of 1943. The UPA is presented as an inclusive, multi-ethnic organization. The hero reminds the viewers that ethnic minorities, such as Armenians, Azerbaijanis, Jews, and Kazakhs were allowed in the UPA. ${ }^{93}$

\section{Nationalist assessments of Schutzmannschaft Battalion 201}

More research is needed in order to establish the exact role and whereabouts of the 201st Battalion and its activities. Older pro-Oun/pro-UPA accounts tend to overlook or ignore the period between August 1941 and January 1943 entirely. ${ }^{94}$ Recent accounts either diminish the importance of his whereabouts in 1942, or portray Shukhevych's presence in Belarus as a benign tutorial in patriotism for the Belarusian population, an opportunity for them to advance the relatively underdeveloped Belarusian national consciousness. ${ }^{95}$ They also deny that there were any 'real' partisans in Belarus at this point, or, alternatively, that there were civilian victims of the activities of the Schutzmannschaft Battalion 201. 'In Belarus, the members of the battalion strived to help the local population in any way they could - even though it was strictly forbidden,' wrote Myroslav Kal'ba (1916-2013), the last surviving veteran of Schutzmannschaft Battalion 201 in 2005. ${ }^{96}$ Nationalist historians agree:

On February 20, 1942, the Legion was sent on military operations. It was sent to a part of Belarus, terrorized by Muscovite-MGB partisans. Much like in the adjacent Ukrainian territories, [the MGB] terrorized the population

93 The portrayal of the UPA as a multi-ethnic organization has become a cornerstone in the pro-UPA narrative, often used in response to allegations that the organization indulged in anti-Semitic activities. Yet, even the Schutzmannschaft Battalions were multi-ethnic. For instance, Turkmens and Uzbeks served in Ukrainian Schutzmannschaft Battalion 134.

94 Hryhorij Waskowycz, Roman Šucheryč - Kommandeur das Befreiungskrieges: Aus Anlass des 3o. Todestages (München: Ukrainische Freie Universität, 1981); Petro Mirchuk, Roman Shukhevych (Gen. Taras Chuprynka): Komandyr armï̈ bezsmertnykh (New York, Toronto and London: Tovarystvo kolyshnikh voiakiv UPA v zSA, Kanadi i Evropi, 1970), 108; Vasyl' Kuk, Heneral Roman Shukhevych: Holovnyi komandyr Ukrains'koi postans'koi armï (UPA) (Kyiv: Biblioteka ukraintsia, 1997), 36-37.

95 Such was Pobihushchyi-Ren's own assessment of the battalion's role in Belarus. Ievhen Pobihushchyi-Ren, Mozaika moikh spomyniv. Tom druhyi (Munich and London: Ievhen Pobihushchyi-Ren and the Association of Ukrainian Former Combatants in Great Britain, 1985), 243.

96 Myroslav Kal'ba, DUN v rozbudovi UPA (Detroit and Ternopil': Dzhura, 2005), 103. 
mercilessly, purposely provoking the German Army and their Polish allies into harsh punitive actions .... During its nine-month protective assignment the officers and soldiers of the Legion took every chance to work to enhance the national consciousness of the local population and to implant a conviction that a free and prosperous life is possible only in a powerful, independent state. With that aim the officers and the instructors provided specialized education for hundreds of young Belarusians, preparing them for struggle, not only against the Russian-Bolshevik invaders. This could not be talked about openly. Yet, the Ukrainian legionnaires were able to rescue many Belarusian patriots, supporters of state independence from both the Gestapo, and the MGB, which operated under the auspices of Bolshevik partisans. There were many such cases, when such people were able to engage [the local Belarusians] in serious battles or assist them through powerful military support. ${ }^{97}$

\section{Memory Management}

Under President Iushchenko, most Ukrainian textbooks came to present Shukhevych in a very favorable light. 'Relentlessly and almost infallibly, the OUN and the UPA are portrayed as victims and not perpetrators,' writes Swedish historian Johan Dietsch. ${ }^{98}$ This perspective of Ukrainian resistance is set up in deliberate contrast to the Soviet narrative of unity with Russia as the natural state of affairs for Ukraine. The post-socialist perspective is juxtaposed with the 'a-historic, amoral, and a-ethical realm' of Soviet socialism. The new, 'national' history is presented as 'true history', in contrast to the 'false Soviet history.' ${ }^{9} 9$

97 Duzhyi, Roman Shukhevych, 145-146, citing Druzhyny Ukrains'kykh Natsionalistiv u 1941-1942 rokakh, 65, 88. This collection of memoirs, the only published account besides Pobihushchyi, was also used as the basis for Posivnych's account of Shukhevych's whereabouts in 1941-1942 in volume 45 of Litopys UPA, 29.

98 Johan Dietsch, Making Sense of Suffering:Holocaust and Holodomor in Ukrainian Historical Culture (Lund: Lund University 2006), 172; Marples, Heroes and Villains, 132-141, 277-278; and Wilfred Jilge, 'The Politics of History and the Second World war in Post-Communist Ukraine (1986/1991-2004/2005),' Jahrbücher für Geschichte Osteuropas 54 (2006): 62.

Peter Niedermüller, 'Der Mythos der Gemeinschaft: Geschichte, Gedächtnis und Politik im heutigen Osteuropa,' in Umbruch im östlichen Europa: Die nationale Wende und das kollektive Gedächtnis, ed. Andrea Corbea Hoise, Rudolf Jaworski and Monika Sommer (Innsbruck: Studien Verlag, 2004), 11-26. On the use of history in the period of the dissolution of the USSR, see also: Klas-Göran Karlsson, Historia som vapen: Historiebruk och Sovjetunionens upplösning 1985-1995 (Stockholm: Natur och Kultur, 1999), 57-61. 
For the past decade, the perhaps most influential promoter of Banderite heritage in Ukraine has been the young and charismatic Volodymyr V'iatrovych (b. 1977) ${ }^{100}$ At the age of twenty-five, he became the driving force of an oun(b)affiliated 'front' organization Tsentr doslidzhen' vyzvol'noho rukhu [TsDVR; The Center for the Study of the Liberation Movement], aimed at popularizing and promoting the legacy of the OUN and UPA. ${ }^{101}$ Having played an active part in the so-called Orange Revolution of 2004, Iushchenko appointed him director of the Haluznyi Derzhavnyi Arkhiv Sluzhba Bezpeky Ukrainy [HDA SBU; Central Archives of the Ukrainian Security Services] in 2008, a position he held until the election of Ianukovych. ${ }^{102}$ V'iatrovych has invested significant efforts to establish Shukhevych as a national hero and absolving the organizations he

100 On V'iatrovych's Institute and his memory activism, see Per A. Rudling, The OUN, the UPA, and the Holocaust: A Study in the Manufacturing of Historical Myths (Pittsburgh: The Center for Russian and East European Studies, University of Pittsburgh, 2011); Per A. Rudling 'Warfare or War Criminality?' Ab Imperio, no. 1 (2012): 356-381; Rossoliński-Liebe, Stepan Bandera, 476-479; Grzergorz Rossoliński-Liebe, 'Debating, Obfuscating and Disciplining the Holocaust: Post-Soviet Historical Discourses on the OUN-UPA and Other Nationalist Movements,' East European Jewish Affairs 42, no. 3 (2012): 207-208; John-Paul Himka, 'The Lontsky Street Prison Memorial Museum: An Example of Post-Communist Holocaust Negationsm,' in Perspectives on the Entangled History of Communism ad Nazism: A Comnaz Analysis, ed. Klas-Göran Karlsson, Johan Stenfeldt, and Ulf Zander (Lanham, MD: Lexington Books, 2015), 137-166.

101 Sviatoslav Lypovets'kyi, oUN banderivtsi:Frahmenty diial'nosti ta borot'by (Kyiv: Ukrains'ka Vydavycha Spilka, 2010), 84.

102 After the overthrow of Ianukovych in 2014, V'iatrovych was appointed director of the Ukrainian Institute of National Memory, with considerable influence of the government's memory policy, even of the drafting of legislation. On the Ukrainian Institute of National Memory, see Georgii Kas'ianov, 'K desiatiletiia Ukrainskogo institute natsional'noi pamiati (2006-2016), Historians.in.ua, January 14, 2016, accessed February 19, 2016, http://historians.in.ua/index.php/en/dyskusiya/1755-georgij-kas-yanov-k-desyatiletiyu -ukrainskogo-instituta-natsional-noj-pamyati-2006-2016. In May, 2015, V'iatrovych, together with Iuryi Shukhevych (b. 1933), the son of the UPA commander, Soviet-era dissident and radical nationalist, drafted a set of laws banning Soviet symbols, outlawing the Communist Party, and prohibiting 'disrespect' for the 'fighters of Ukrainian statehood in the 2oth century, such as the OUN and UPA. The laws have been sharply criticized by historians, human right groups, and the Council of Europe: David R. Marples et al., 'Open Letter from Scholars and Experts in Ukraine Re. the So-Called "Anti-Communist Law", Krytkya, April 2015, accessed April 6, 2016, http://krytyka.com/ en/articles/open-letter-scholars-and-experts-ukraine-re-so-called-anti-communist-law; Jared McBride, 'How Ukraine's New Memory Commissar Is Controlling the Nation's Past,' The Nation, August 13, 2015, accessed March 31, 2016, http://www.thenation.com/article/ how-ukraines-new-memory-commissar-is-controlling-the-nations-past/. 
led from allegations of anti-Semitism and collaboration with the Third Reich. A cornerstone of his strategy has been to seek to deflect the significant emerging scholarship of the oun(b)'s involvement in the Holocaust and systematic massacres of Poles by an extensive focus on a handful of Jews who served in the UPA, mainly as physicians and nurses. ${ }^{103}$ In an apparent attempt to reconcile the veneration of the ethno-nationalists with European expectations of recognition of the Holocaust, Iushchenko's legitimizing historians working in the SBU archives sought to establish a narrative of World War II in which Ukrainian nationalists and Jews fought together, as comrades-in-arms against a common Bolshevik-Muscovite enemy. They employed a highly selective use documents, systematically downplaying the oun's anti-Semitism, ignoring the nationalists' mass murder of thousands, and focusing instead on a handful of exceptions. ${ }^{104}$ Still, this marked a departure from a tendency in the nationalist historiography to portray Jews as enemies and tormentors of Ukrainians, and as accomplices in Communist crimes. ${ }^{105}$ Unlike the narrative produced by the organizations run by V'iatroych, a number of studies, independently of one another, all concur that the anti-Semitism of the oun was radicalized over the 1930s, reaching a high point in $1941-43{ }^{106}$ There is no shortage of radical, even eliminatory anti-Semitism in the writings of senior oun ideologues

103 Rudling, The OUN, the UPA, and the Holocaust, 28-32.

104 'V'iatrovych,' Canadian historian John-Paul Himka writes, 'manages to exonerate the ouN of charges of antisemitism and complicity in the Holocaust only by employing a series of highly dubious procedures: rejecting sources that compromise the oun, accepting uncritically censored sources from émigré oun circles, failing to recognize antisemitism in oun texts, limiting the source base to official oun proclamations and decisions, excluding Jewish memoirs, refusing to consider contextual and comparative factors, failing to consult German document collections, and ignoring the mass of historical monographs on his subject written in the English and German languages.' John-Paul Himka, 'True and False Lessons from the Nachtigall Episode,' Brama, March 19, 2008, accessed March 19, 2008, http://brama.com/news/press/2008/03/080319himka_nachtigall.html. See also: Taras Kurylo and John-Paul Himka [Ivan Khymka], 'Iak oun stavylasia do ievreiv? Rozdumy nad knyzhkoiu Volodymyra V'iatrovycha Stavlennia oun do ievreiv: Formuvannia pozytsii na tli katastrofy,' Ukraina Moderna 13 (2008): 252-265.

105 See, for example, the oun(b)-affiliated historian Petro Mirchuk, My Meetings and Discussions in Israel (Are Ukrainians 'Traditionally anti-Semites'?) (New York, London and Toronto: Ukrainian Survivors of the Holocaust, 1982), 66. And, on the diaspora press in North America:John-Paul Himka, 'A Central European Diaspora under the Shadow of World War II: The Galician Ukrainians in North America,' Austrian History Yearbook 37 (2006): 29.

106 Himka, 'A Central European Diaspora, 22; Taras Kurylo, "The "Jewish Question" in Ukrainian Nationalist Thought of the Interwar Period,' Polin: Studies in Polish Jewry 26 (2014): 233-258; H. V. Kasyanov, 'Ideolohiyia oun: Istoryko-retrospektyvnyi analiz,' Ukrains'kyi istorychnyi zhurnal, no. 2 (Feb. 2004): 38-39. 
and intellectuals, from both before and after the breakout of the war. ${ }^{107}$ After Stalingrad, the oun leadership systematically manipulated the organization's past. Original documents were retyped, pro-German and anti-Semitic statements omitted, sensitive documents withheld or released selectively, producing a distortingly selective view, which avoided thorny and compromising issues. ${ }^{108}$ V'iatrovych uncritically relied on the nationalists' own doctored accounts while dismissing emerging scholarship as Soviet propaganda. Avoiding the sensitive issues in Shukhevych's biography, he instead focused on the work of the KGB of the Ukrainian SSR to discredit the OUN, ${ }^{109}$ dismissing criticism of Shukhevych as a baseless political campaign against the UPA commander's memory. ${ }^{110}$ The oun's anti-Semitism is reduced to Soviet propaganda lies and the emerging body of scholarship on Ukrainian involvement in anti-Jewish violence to rehash of Soviet propaganda:

According to the canon of Soviet propaganda, anti-Semitism was one of the basic elements of the ideology and the practice of the Organization of Ukrainian Nationalists . . . . Unfortunately, that is the way many contemporary publicists and historians behave, who, in this old manner look at Ukrainian history through the glasses of 'Agitprop.' One of the

107 See, for instance Oleksandr Zaitsev, 'Voenna doktryna Mykhaila Kolodzins'koho,' Ukraina Moderna 20 (2013): 245-256; and Mykhailo Kolodzins'kyi, 'Natsionalistychne povstannia: Rozdil iz pratsi “Voenna doktryna ukrains'kykh natsionalistiv", Ukraina Moderna 20 (2013): 257-295; Grzegorz Rossoliński-Liebe, The Fascist Kernel of Ukrainian Genocidal Nationalism (Pittsburgh: The Center for Russian and East European Studies, University of Pittsburgh, 2015).

108 Himka, 'A Central European Diaspora,' 22; Berkhoff and Carynnyk, 'The Organization of Ukrainian Nationalists,'149; Grzegorz Rossoliński-Liebe, 'Erinnerungslücke Holocaust: Die ukrainische Diaspora und der Genozid an den Juden,' Viertelsjahrhefte für Zeitgeschichte 62, no. 3 (2014): 397-430, on Shukhevych, see 421-424. On Mykola Lebed's doctoring on documents on the Volhynian massacres, see Krzysztof Łada, 'Creative Forgetting: Polish and Ukrainian Historiographies on the Campaign against the Poles in Volhynia during World War II,' Glaukopis, no. 2/3 (2005), 346.

109 'U Sluzhbi bezpeki Ukrainy...' and 'Dokumenty sвU sprostovuiut' zvynuvachennia proty batalionu "Nakhtihal", Press release, Press Office of the Embassy of Ukraine in Canada, no. 20, March 22, 2008, accessed March 22, 2008, http://www.ukremb.ca/canada/ua/news/ detail/11684.htm; Volodymyr V'iatrovych, 'Kukhnia antysemityzmu vid KG B,' in Isotriia z hryfom "Sekretno": Taemnytsi ukrains'koho mynuloho z arkiviv KG B, Volodymyr V'iatrovych (L'viv: Tsentr doslidzhen' vyzvol'noho rukhu, 2011), 239-255.

110 See, for instance, the article by his wife, TsDVR-affiliated journalist and editor Iaryna Iasynevych, 'V'iatrovych: Kampania proty Shukhevycha ne maie istorychnoï osnovy,' Narodna Pravda, March 4, 2008, accessed March 16, 2008, http://narodna.pravda.com.ua/ history/47cd371e88bo5/. 
most wide-spread accusations against the Ukrainian nationalists is the allegation of their participation in the anti-Jewish pogroms in L'viv in the beginning of July, 1941. ${ }^{111}$

\section{Rehabilitation with Difficulties}

Iushchenko's rehabilitation of Shukhevych did not benefit Ukrainian-Jewish reconciliation. Moshe Kantor, the head of the European Jewish Congress, describing Shukhevych as a 'Nazi collaborator' and citing the growth in antiSemitism and far-right activism in Ukraine, refused to accept a posthumous Order of Hero of Ukraine from Iushchenko on behalf of Major Anatolii Shapiro, a Soviet Jewish commander who liberated Auschwitz in $1944 .{ }^{112}$

During a state visit to Israel the following month, Iushchenko was sharply criticized for his decision to honor Shukhevych. At Yad Vashem, Iushchenko was confronted by the Chairman of its Council, Joseph (Tommy) Lapid (1931-2008), a Holocaust survivor and former deputy Israeli Prime Minister. A journalist and politician - not a historian - Lapid alleged that he had proof that Shukhevych participated in the July, 1941, Pogrom in L'viv. ${ }^{113}$ To this Iushchenko responded that, 'I have materials, documents, saying that in the course of grander context of Ukrainian insurgency Shukhevych signed a petition that prohibited massive persecutions (of civilians), even adding that 'there is not a single fact to confirm that any single Ukrainian national liberation organization participated in punitive actions, the deportation and murder of Jews.' 114

111 Volodymyr V'iatrovych, 'Iak tvorylasia lehenda pro Nachtigall,' Dzerkalo Tyzhnia, no. 6 (685), February 16-22, 2008, accessed March 16, 2008, http://www.dt.ua/300o/3150/62036/.

112 'Jewish Leaders Snub Ukraine Award Citing Rise in anti-Semitism,' Kyiv Post, October 24, 2007, accessed April 8, 2016, https:/www.kyivpost.com/article/content/ukraine-politics/ jewish-leaders-snub-ukraine-award-citing-rise-in-a-27668.html.

113 'Visit of Ukrainian President Yuschenko to Yad Vashem: Yad Vashem Chairman Chalev Thanks Ukrainian President Yushchenko for Instructing the Relevant Professionals to Reach an Agreement regarding the Bruno Schultz Murals, Chairman of the Council Lapid Protest Granting Honor to man Involved in Murder of Jews During Holocaust,' Yad Vashem website, accessed April 10, 2008, http://yad-vashem.org.il/about_yad/what_new/ data_whats_new/Yuschenko.html.

114 'Yushchenko ne dospustyt' ksenofobii, ale i proty shtampiv,' Ukrains'ka Pravda, November 15, 2007, accessed November 18, 2007, http://www.pravda.com.ua/news/2007/11/15/66920 .htm. 
The Lapid-Iushchenko confrontation at Yad Vashem resembled the debate in Ukraine. Lapid's objections resembled the attitudes towards Shukhevych, common in the east and the south of the country, and within the Ukrainian left. 'Sometimes you can be both a hero of Ukrainians and a murderer of Jews,' Lapid summarized his position. ${ }^{115}$ On January 6, 2008, Lapid further embellished his claims, stating that 'We have an entire file that certifies that Shukhevych participated in mass murder. The Ukrainian side has not contacted us with a request to handle over those documents. If we were to receive such a request, I think we would be happy to respond to it.'116

V'iatrovych skillfully took advantage of the opportunity Lapid had provided. He lost no time organizing and heading a delegation to Yad Vashem. In Jerusalem, V'iatrovych requested to see this folder, to which the Yad Vashem archivists could only confirm what they already knew: that no such file existed.117 V'iatrovych returned triumphantly to Ukraine, declaring the allegations baseless, proclaiming Shukhevych's innocence. Lapid's irresponsible claims served Shukhevych's hagiographers a propaganda victory at the expense of Yad Vashem's authority. More seriously, given the significant media noise surrounding this episode, it had an adverse effect on the Holocaust education and awareness Yad Vashem is dedicated to promote. The pro-Shukhevych camp used Lapid's misleading intervention as a vindication not only of Shukhevych, but also of the organizations he led, the oun(b) and the UPA, from allegations of antiSemitism and collaboration in the Holocaust. ${ }^{118}$ The dynamics of the exchange between Lapid and Iushchenko - two experienced politicians - highlight the complexity of Ukrainian-Jewish relations. Ukrainian nationalists deliberately overinterpreted Lapid's attack as an expression of deep-seated Jewish stereotypes of the Ukrainian pogromshchik, some of the reactions emanating in Ukraine invoked the image of the Jews as the stooges of Bolshevism and Moscow. The Kyiv Post editorialized that

it's time the worldwide Jewish community, known for its high standards in scholarship, quit being the pawns of the Soviet, and now Russian,

115 'Ukraine President Defends National Hero,' UNIAN, November 16, 2007, accessed January 17, 2008, http://www.unian.net/eng/news/news-221993.html.

116 'SBU sprostuvala Iad Vashem shchodo Shukhevycha,' ввс Ukrainian, March 4, 2008.

117 'V arkhivi izrail'skoho memorial'noho kompleksu "Iad Vashem" nemae dos'e na Romana Shukhevycha,' Sluzba bezpeki Ukraïny, March 4, 2008, accessed April 23, 2008, http:// www.ssu.gov.ua/sbu/control/uk/publish/article?art_id=76079\&cat_id=73817.

118 John-Paul Himka, 'Debates in Ukraine over Nationalist Involvement in the Holocaust, 2004-2008,' Nationalities Papers 39, no. 3 (2011): 363-365. 
propaganda machine .... Instead of over-relying on Russian scholarship, distorted by Soviet nostalgia and post-Soviet nationalism, Jewish scholars should consider Ukrainian scholarship, and that of other post-Soviet satellite states, as a more reliable and objective record of events during those horrid days. ${ }^{119}$

In an open letter to Iushchenko, Roman Krutsyk, the chairman of the Kyiv Memorial Society requested the Ukrainian president to obtain all incriminating documents for the Ukrainian SBU and the Ukrainian Institute of National Memory so that the Ukrainian researchers can ascertain their authenticity. He complained that Israel was pushed into an anti-Ukrainian stance by Russia, and expressed his concern that 'Israel does not want to recognize the Holodomor 120 of $193^{2-33}$ as an act of genocide against Ukrainians,' since it 'only recognizes the Holocaust as the sole genocide in history.' Furthermore, Krutsyk requested Iushchenko to set up a 'state program for patriotic training and education of the citizens of Ukraine.' Krutsyk felt that such a program would 'enlighten every Ukrainian citizen about the truth about the Ukrainian national liberation movement in the 2oth century, especially about the fight of the Ukrainian Insurgent army and the Organization of Ukrainian Nationalists for the freedom and independence of the Ukrainian people. [This is necessary] to counteract any dirty insinuations and manipulations of the national consciousness in regards to that question.121

Shukhevych's admirers reject the notion that there would have been anything unethical in Shukhevych's collaboration with the Germans in 1941 and 1942, and instead compare the role of their hero in 1942 to either that of the Judenräte, de Gaulle, Churchill or the leaders of the struggle against British colonialism. Commenting on Shukhevych's collaboration, V'iatrovych insisted that the oun had adopted an anti-German line from 1941: 'After the Germans

119 'Trust Ukraine scholars,' Kyiv Post, March 13, 2008, accessed April 8, 2016, https://www .kyivpost.com/opinion/editorial/trust-ukraine-scholars-28583.html.

120 Holodomor is the term introduced in the late 1980 s by the Ukrainian diaspora for the man-made famine of $193^{2-} 33$. Along with the veneration of the OUN and UPA, the quest to present the $193^{2-} 33$ famine as a deliberate act of genocide against the Ukrainian nation was a cornerstone in Iushchenko's Geschichtspolitik. On the instrumental use of the famine, see: Heorhii Kasianov, Dance macabre: Holod 1932-1933 rokiv u politytsi, masovii svidomosti ta istoriohrafii (1980-ti - pochatok 200o-kh) (Kyiv: Informatsiino-analitychna ahentsiia 'Nash chas', 2010).

121 Roman Krutsyk, 'Memorial: Pane Prezydente, zaberit' nareshti dokumenty Shukhevycha z IAd Vashem,' Maidan, December 20, 2007, accessed January 17, 2008, http://maidan.org .news/for-print.php3?bn=maidan_mai\&key=1198164610. 
failed to recognize the Act of Renewal of Ukrainian Independence on June 30, 1941 and Stet'sko's government, and instead began to repress its leadership, the oun pursued an anti-German political line.' To the obvious follow-up question, as to why Shukhevych then collaborated with the Abwehr from 1939 and then signed up for the Schutzmannschaften, V'iatrovych answered:

Shukhevych, as an individual, had the right to collaborate with the [German military] intelligence. We cannot overlook that episode, but we also need evaluate the goals he set up for himself. That goal was one - the formation of an armed formation, which could become the kernel of a Ukrainian army. Very many of the officers of the Nachtigall later became commanders of the UPA. And why did France and Britain have the right to collaborate with Germany during 1938-1939, why did the Soviet Union have the right to collaborate with Germany during 1939-1941? ... The OUN-UPA was a force that dared to challenge both totalitarianisms: the German, as well as the Soviet. Even Churchill made compromises with one evil in order to fight the other. ${ }^{122}$

V'iatrovych presupposes that Schutzmannschaft Battalion 201 targeted only the wicked, primarily NKVD agents who terrorized the Belarusians on Moscow's orders, that Shukhevych avoided shedding innocent blood, venturing to state, conclusively, that Shukhevych did not participate in the Holocaust:

Did [Shukhevych] have the right to collaborate with evil Germany? In order to answer that question we again need to evaluate the situation not from the perspective of 2008 , or even 1945 , but only 1941 , when that decision was made. However, for us the German army is synonymous with millions of victims. [To us, it] represents what was put on trial at in Nuremberg in 1945. Yet, in 1941 this all laid in the future .... Yes, Shukhevych fought in 1941-1942 in a German uniform, but donning it does not mean that he assumed responsibility for all crimes, committed by the soldiers of the German army... There are practically no documentary sources on Roman Shukhevych's stay in Belarus, and the [only known] recollections of the activities of that period are the memoirs of one colleague from the Battalion. Despite this, after it has been established that Shukhevych's alleged participation in anti-Jewish actions in 1941 was a hoax, [some

122 Masha Mishchenko, 'Pratsivnyk SBU: My izdyly v Izrail' pobachaty dos'e proty Shukhevycha - a ioho prosto one isnue,' UNIAN, March 25, 2008, accessed April 8, 2008, http://unian.net/news/print.php?id=242913. 
people] have instead sought to disentangle the issue of his possible participation in the pacification against the Belarusian population in 1942. However, if there are no documents, then it will be difficult to prove that Shukhevych did not participate in such actions. Again, there is a presumption of guilt. ${ }^{123}$

V'iatrovych similarly denies that Schutzmannschaft Battalion 201 committed any crimes against civilians:

In Belarus the $201^{\text {st }}$ Ukrainian battalion was not concentrated in one place, as it was protecting bridges over the rivers Biarezina and Dzvina. The detachments in the small villages were also assigned to protect the local German administration. Towards the end of November 1942 the Ukrainian officers decided to maximally curtail the battalions' active participation in German military actions in order to avoid further losses. On December 1, 1942 the soldiers of the battalion refused to renew the contract with the Germans, which led to the arrest of many of them, particularly their leaders. Others, including Roman Shukhevych, were able to escape. All together, many soldiers of the battalion joined the Ukrainian Insurgent Army, where they, as well-prepared soldiers, chose to take up commanding positions. In the functions of that army, defending the Ukrainian population, they fought honorably against their former allies, the Germans. ${ }^{124}$

On the question why Shukhevych did not immediately turn his weapons against the Germans after they had lied to him and arrested the leadership of the oun, V'iatrovych responded:

Let's be realistic. Roman Shukhevych commanded 700 soldiers. The Wehrmacht, at that time, close to half a million. To turn the weapons against the Wehrmacht in 1941 and tell them: 'now Roland and Nachtigall will fight the Wehrmacht' would have meant that they would have been killed on the spot.... Until the end of 1942 the soldiers were bound by a

123 V'iatrovych, 'Roman Shukhevych: soldat.' Historian Tarik Cyril Amar, then the Academic Director of the Center for Urban History of East Central Europe in L'viv, and specializing on Second World War in Western Ukraine, sought to take V'iatrovych to task, but his rebuttal, even though initially accepted by Ukrains'ka Pravda, was never published, and Amar never heard back from the newspaper. The rebuttal was only published much later, in a different publication. Tarik Cyril [Syryl] Amar, 'Roman Shukhevych: Fantaziia,' Zaxid. net, August 26, 2008. On the discussion, see Himka, 'Debates in Ukraine,' $364-365$.

124 V'iatrovych, 'Iak tvorylasia lehenda pro Nachtigall.' 
contract, which tied them to the Schutzmannschaft battalion. When the contract ended, those people declared: we will no longer serve with you. That decision cost many of them their lives.

Q: They say that after 1942, Shukhevych fought against Belarusian partisans and Poles?

A: The Schutzmannschaft battalion, in which the former Nachtigall members, among them Shukhevych, served, ended its activities in the end of 1942. After that the majority of the boys joined the ranks of the Ukrainian Insurgent Army. And anyway, what partisans were there in 1942 in Belarus?

Q: Vasil Bykau ${ }^{125}$ writes, that there were...

A: Vasil Bykau was a novelist. Let's look at the documents. The documents show that there were special groups, created under the leadership of the NKVD, who infiltrated and carried out acts of sabotage behind the German lines. To call them partisans is difficult, since partisans are rebels, organized by the local population.

Q: As a historian, can you say that Shukhevych did not participate in [anti-]Jewish pogroms?

A: Yes.

Q: Likewise, can you say that Shukhevych did not participate in the killing of peaceful Belarusian and Polish civilians?

A: Very interesting question regarding peaceful population during partisan warfare .... In conventional warfare, one soldier differs from another by his uniform. Is it possible to consider Poles or Belarusians a peaceful population, if they at day time work as ordinary villagers, but in the evening arm themselves and attack the village? How should they be regarded - as Polish or Ukrainian [soldiers]? With a machine gun - he is a soldier, with a hoe - a peaceful civilian? When such a person is killed in an armed conflict, should he be regarded as a killed civilian or as a military casualty?126

\footnotetext{
125 Vasil Bykau (1924-2003) was one of the most important Belarusian writers, known, in particular for his realistic accounts of World War II, a conflict of which he himself was a veteran. On Bykau, see Zina J. Gimpelevich, Vasil Bykau: His Life and Works (Montreal: McGill-Queen's University Press, 2005).

126 Ibid.
} 
V'iatrovych's narration differs little from that of the Schutzmänner themselves, which lack any reference to abuse or atrocities committed against the local population in Belarus, whereas killings, and attacks carried out by the pro-Soviet partisans are described in great detail. ${ }^{127}$

An alternative explanation to the question of Shukhevych's whereabouts was offered by Parmen Posokhov, an 'independent researcher,' who questioned the claim that Schutzmannschaft Battalion 201 guarded communication infrastructure, such as bridges over the rivers Biarezina and Dzvina. Posokhov argued that the protecting the bridges of the Biarezina river was not included in the battalion's responsibilities, that the Lepel' railroad station was little more than a shack, the town connected to the outside world by just one paved road, and that its population was so small, that it would be an unlikely place to store weapons and ammunition. As an alternative explanation, Posokhov suggested that there could have been a secret Abwehr training camp in Lepel'. There was a sanatorium twenty-eight kilometers from Lepel', Lesnye Ozera, where the Germans vacationed. They had entrusted its protection to members of the oun. ${ }^{128}$ Posokhov refers to the memoirs of Nikolai Obryn'ba, a Soviet Pow, interned in Lepel', who mentioned German 'diversion schools in Lepel', which prepared the saboteurs for provocations, intelligence work, the mining of roads, the destruction of wells, and the murder of partisan commanders. ${ }^{129}$

Ukrains'ka Pravda published a similar assessment by Serhii Hrabovs'kyi, a member of the Association of Ukrainian Writers:

[T] he supreme commander of the UPA and the people he commanded were hardly any more 'collaborators' than, say, the leaders of the Judenräte in the Nazi-occupied territories, and no more 'fascists' than the Gaullists of the French resistance.... Strictly speaking, almost all serious researchers speak about the absence of a serious popular partisan movement and

127 Pobihushchyi-Ren, Mozaika moikh spomyniv; Myroslav Kal'ba, Druzhyny Ukrains'kykh Natsionalistiv (Detroit: DUN, 1994); Myroslav Kal'ba, My prysiahaly Ukraini: DUN 1941-1942 (L'viv: Memuarna biblioteka NTsh, 1999); Myroslav Kal'ba, U lavkah druzhynnykiv: spohady uchasnykiv. Materialy zibrav i vporiadkuvav Myroslav Kal'ba (Denver: Vyd-ia Druzhyny ukrains'kykh natsionalistiv, 1982); Myroslav Kal'ba , ed., Druzhyny Ukraïns'kykh Nationalistiv v 1941-1942 rokakh (n.p: Vyd-ia Druzhyny ukraïnsks'kykh nationalistiv, 1953), 63, 71, 77-78. Pobihushchyi even presents the Schutzmänner as victims: 'The Legion did not carry out a single execution. Instead, unfortunately, a soldier from the Legion was executed [by the Germans] (I do not remember his name).' Ibid., 40.

128 Posokhov, 'Shukhevych.'

129 Nikolai Ippolitovich Obryn'ba, Sud'ba opolchentsa (Moscow: Iauza, Eksmo, 2005), 283-284, accessed November 18, 2007, http://militera.lib.ru/memo/russian/obrynba_ni/ index.html. 
battles between 'real' partisans (and not intelligence officers and NKVD provocateurs) and the police and parts of the Wehrmacht until 1943. In regards to the 201st battalion, scholars and publicists of diametrically opposed ideological perspectives agree that it did not rush into battle, but at times reached a neutrality agreement with the partisans (Shukhevych, in particular, was interested in such an agreement), though, without doubt, there were battles with victims on both sides. ${ }^{130}$

Using examples from 1943, Hrabovs'kyi focuses on atrocities of pro-Soviet partisans against the local Belarusian population. After giving an example of how Soviet partisans cut the throat of an under-aged girl, Hrabovs'kyi asks, rhetorically:

It was this kind of 'operations' the Kutuzov Soviet partisan division, commanded by Israil Lapidus carried out. The people were of the same lot as Lazar Kaganovich, who pathetically stressed, 'I am not a Jew, I am a Bolshevik!' Do we need to question whether the Ukrainian nationalists had the moral right to fight such partisans? ... Naturally, among the Soviet partisans as well as with the oun there were various kinds of people. Of course it is not possible to portray the warriors of the UPA and their commanders as angels - as the last supreme commander of the insurgents, Vasyl' Kuk put it: 'they killed and we killed.' My purpose is not to 'justify' Roman Shukhevych - after all, his political principles, expressed in the program of the Third Congress of the oun(b), have today entered the Ukrainian constitution, while the Bolshevik ideology has been thrown on the dust heap of history .... I call on politicians and journalists, among them Israeli: do not rush to make simple conclusions regarding 'Ukrainian fascists' 131

130 Serhii Hrabovs'kyi, 'Tak proty koho zh voiuvav Shukhevych u Bilorusi?' Ukrä̈ns'ka Pravda, November 13, 2007, accessed November 18, 2007, http://www.pravda.com.ua/ news/2007/11/13/66774.htm.

131 Hrabovs'kyi refers to the partisan Izrail Abramovich Lapidus, commander of the Kutozov detachment of the second Minsk partisan brigade, and the secretary of the Minsk rural underground raion committee of the KP(b)B. E. G. Ioffe, G. D. Knat'ko and V. D. Selemenev, Kholokost v Belarusi, 1941-1944 (Minsk: Natsional'nyi Arkhiv Respubliki Belarus', 2002), 219-221. It should be noted that Jewish commanders among Soviet partisan formations were rare, as the Soviet authorities deliberately strived to diminish the number of Jews in leading roles in the partisan movement in order to combat the stereotype of 'Judeo-Bolsheivsm.' Leonid Smilovitsky, 'Antisemitism in the Soviet Partisan Movement, 1941-1944: The Case of Belorussia,' Holocaust and Genocide Studies 20, no. 2 (2006): 217; Evgenij Rozenblat, 'Belarus: Specific Features of the Region's Jewish Collaboration and Resistance,' in Collaboration and Resistance During the Holocaust: Belarus, Estonia, Latvia, 
Shukhevych's son Iuri, who received the highest state award on behalf of his father, maintains the view that Shukhevych was just an independence fighter, whose alliance with Nazi Germany was strictly tactical:

Let us look at the events of World War II in other countries. In Burma there was Aun Sang, who formed military formations on the side of the Japanese to fight the English colonizers. As a result, Burma became an independent state in 1948! The Indian legions, created by Chandra Bos the leader of Indian National Congress - fought England as an ally not only of the Japanese, but also of the Germans. It was formed in Europe out of captive Hindus. This is not held against them. The Union of Young Officers, which under the leadership of Gamal Abdel Nasser fought for the independence of Egypt against the English, received assistance from Mussolini. That cooperation did not discredit Nasser [in the eyes of the Soviets] who, after becoming president of Egypt, received the order of Hero of the Soviet Union!

\section{Q: Nachtigall, together with Roland, formed the Schutzmannschaft} Battalion 201, which fought partisans in Belarus. Is it correct that Roman Shukhevych on October 14, 1942, did not desert from the battalion, but was assigned the task to track down Jews, hiding in Belarusian and Ukrainian forests?

A: Nonsense. The dissolution of the battalion began in the fall of 1942. Initially the privates were dismissed, but my father stayed there until January 1943. And when the leader of the battalion was taken to Germany my father, at the time in Konotop or in Bakhmach, was informed that Gestapo may arrest him. Also, the leading members of the Provid of the oun, led by Bandera, had been arrested, as we know, already in July of 1941 ... What kind of killing of Jews in Ukraine could there have been, when he was stationed around Vitsebsk? ${ }^{132}$

Lithuania, ed. David Gaunt, Paul A. Levine and Laura Pelosuo (Bern: Peter Lang, 2004). Lazar Kaganovich undoubtedly played important roles in the $1932-33$ famine as well as the Great Terror, but Hrabovs'kyi's linking of Jews to communism, and his not-so-subtle implication that being Jewish has something to do with being a mass murderer, smacks of a rather problematic essentialism. He provides no explanation as to how Shukhevych's principles or the oun(b)'s 1943 political programs would have entered the Ukrainian constitution.

132 'Iurii Shukhevych: Ia hadaiu, Prezydent udostoït' moho bat'ka naivyshchoi nahorody,' L'vivs'kyi portal, July 6, 2007, accessed February 22, 2008, http://portal.lviv.ua/citizens/ 2007/07/06/174417.html. 
The disagreements regarding Shukhevych's whereabouts in 1942 concern not only the interpretations of the events, but also about basic facts surrounding the German occupation of Belarus. Shukhevych's critics portray him as a war criminal; his admirers either overlook this episode or regard his collaboration with Nazi Germany as unproblematic.

\section{Conclusion}

Independence has called for a re-evaluation of Ukrainian history. As the polarized discussions regarding the legacy of Shukhevych and other oun leaders show, this process is not without its difficulties. At the heart of this discussion lies the question of what sort of society Ukraine should be, its geopolitical orientation, and what sort of 'national heroes' and role models this society needs. Some commentators have argued that the glorification of the leaders of the OUN and UPA does not mean rehabilitation of their ideology:

One piece of good news, however, is that attempts to rehabilitate oun and UPA followers as freedom fighters and glorify their leaders as national heroes, are not accompanied by attempts to revive the ideology of integral nationalism or promote any kind of militancy and intolerance. The emphasis typically is put on ethical rather than ideological values. The UPA fighters ... are praised first of all for their patriotism and commitment to the national-liberation cause, for their idealism and dedication, for spiritual strength and self-sacrifice. We see here the makings of a heroic myth to counterbalance the long-dominant image of the impeccable Red Army. Any nation invents some historical myths of the sort, and we can only hope that every nation will be able to keep the irrational energy of its historical myths under rational control. ${ }^{133}$

A historian may object that this sort of semi-mythical, moral tales of the exploits of 'national liberators' belongs in the nineteenth, rather than the twentyfirst century, and that the role of the professional historian is to be to facilitate the understanding of the past rather than producing edifying patriotic myths, using the organs of state security. The professional historian would also raise

133 Mykola Riabchuk, 'Ukraine: Neither Heroes nor Villains: Review of Heroes and Villains: Creating National History in Contemporary Ukraine, by David Marples (Budapest: Central European Press, 2007),' Transitions Online, February 6, 2007. 
the question of whether it is possible to turn Shukhevych into a national hero without legitimizing the ideology of the organizations he led.

'Ukraine for Ukrainians' was implemented as brutal policy. Members of both wings of the oun engaged in pogroms in 1941 and ethnic cleansing in 1943, in the ranks of the Wehrmacht, the Ukrainian police in occupied Ukraine, the UPA and Waffen-ss Galizien. The ideology of the oun(b) was not static. Yet, at the same time as the oun(b) officially moderated its political positions in the summer of 1943, the UPA was systematically massacring the Polish population of Volhynia, expanding the ethnic cleansing to eastern Galicia in $1944 .{ }^{134}$ While Bandera himself remained a committed anti-democrat until his death at the hands of a Soviet assassin in 1959, the organization went through periods when its totalitarianism was toned down. ${ }^{135}$

The nationalistic accounts tend to focus on what has been done to Ukrainians and not by them. ${ }^{136}$ In the quest for victim status it is easily forgotten that Ukrainians were found not only among the victims, but also among the perpetrators of the totalitarian regimes. ${ }^{137}$ Referring to this phenomenon as 'the nationalism of the victim,' Timothy Garton Ash notes that the focus on the suffering of one's own group often comes at the expense of the interest taken in the suffering of others, that it is linked to 'a reluctance to acknowledge in just measure the sufferings of other peoples, an inability to admit that the victim can also victimize. ${ }^{\prime 38}$ Günther Grass - of all people - referred to the uneven and selective approach of dealing with the past as 'disabled memory.'139

134 Ivan Lysiak-Rudnyts'kyi, 'Natsionalizm i totalitaryzm (Vidpovid' M. Prokopovi), Journal of Ukrainian Studies 7, no. 2 (1982): 83-85; Per A. Rudling, 'Theory and Practice: Historical Representation of the War Time Activities of OUN-UPA (the Organization of Ukrainian Nationalists - the Ukrainian Insurgent Army), East European Jewish Affairs 36, no. 2 (2006): 163-189; and Łada, 'Creative Forgetting,' 340-375.

135 John Armstrong, Ukrainian Nationalism, 3rd ed. (Englewood, co: Ukrainian Academic Press, 1990), 117.

136 John-Paul Himka, 'War Criminality: A Blank Spot in the Collective Memory of the Ukrainian Diaspora,' Spaces of Identity 5, no. 1 (2005), 13-14.

137 Andreas Kappeler, Der schwierige Weg zur Nation: Beiträge zur neuern Geschichte der Ukraine (Vienna: Böhlau, 2003), 19.

138 Timothy Garton Ash, 'The Life of Death,' The New York Review of Books, December 19, 1985, 32 .

139 Richard S. Esbenshade, 'Remembering to Forget: Memory, History, National Identity in Postwar East-Central Europe,' Representations, no. 49 (1995), 84, citing Gunter Grass, 'Losses,' Granta 42 (1992): 102. 
Much as both sides in the controversy squabbled over caricatures which are a legacy of Soviet and nationalist propaganda, the designation of Shukhevych as a national hero is best understood as continuing this tradition. Ironically, the controversy took place at a time when recent scholarship raised very serious question about the suitability of the OUN and UPA as symbols of an aspiring democracy. Rather than more myth making, Ukrainian society may arguably be better served by critical inquiry and critical engagement with the difficult episodes of it recent past. 